\title{
STICKY INCOME INEQUALITY IN THE SPANISH TRANSITION (1973-1990)*
}

SARA TORREGROSA-HETLAND

University of Barcelona ${ }^{\mathrm{a}}$

\begin{abstract}
This paper investigates the evolution of income inequality in Spain during its transition to democracy, suggesting a method for the correction of under-reporting of earnings and profits in the Household Budget Surveys' data. The contribution is twofold: the methodological proposal, based on income-expenditure discrepancy and scaling-up to National Accounts, improves on previous work and can be useful for similar historical sources in other countries. Second, its application results in an alternative history of the distribution of income in this case, changing the levels and also the observed trend. Previous literature asserted a substantial equalisation, related to the democratisation process, while after the adjustment inequality in disposable income is shown to have been quite persistent.
\end{abstract}

Keywords: income inequality, income under-reporting, household surveys, democratisation

JEL Code: D31, N34

\footnotetext{
* Received 18 December 2014. Accepted 23 April 2015. This paper is part of the PhD dissertation project "Tax system and redistribution: the Spanish fiscal transition (1960-1990)», under the supervision of Alfonso Herranz-Loncán and Alejandro Esteller-Moré, to whom the author was grateful. The author acknowledges financial support from the Spanish Ministry of Education's (FPU scholarship) and Research Project ECO2012-39169-C03-03. She also thanks the team from Carlos III University who worked on the Household Budget Surveys data, and comments from seminar participants in Santiago de Chile and Bogotá and two anonymous referees. Emmanuel Saez hosted her at UC Berkeley while culminating this research; she is also grateful for his insights. All errors are the author's own.

a Department of Economic History and Institutions. 690 Avda. Diagonal, 08034 Barcelona, Spain. storregrosa@ub.edu
} 


\section{RESUMEN}

Este artículo analiza la evolución de la desigualdad de rentas en España durante la transición a la democracia, proponiendo un método para corregir la infra-declaración de ingresos en las Encuestas de Presupuestos Familiares. La contribución es doble: la metodología, basada en la discrepancia entre rentas y gastos y en el ajuste a Contabilidad Nacional, puede ser de utilidad para fuentes históricas similares en otros países. En segundo lugar, su aplicación resulta en una interpretación alternativa en este caso, al cambiar los niveles de desigualdad y también la tendencia observada. Si la literatura anterior había tratado de una sustancial mejora en la distribución, vinculada a la democracia, tras el ajuste efectuado la desigualdad en la renta disponible se muestra bastante persistente.

Palabras clave: distribución de la renta, infra-declaración de rentas, encuestas de hogares, democratización

\section{INTRODUCTION}

Income inequality is at the center of many debates. Political power, economic development or taxation are all related to the distribution of resources in any given country - or the world. This study takes a dynamic national perspective and investigates how inequality changed during a period of transition from dictatorship to democracy.

The contribution of the paper is twofold. On the one hand, it is inserted in the debate about the distributional consequences of political transitions, providing an example where income inequality did not substantially decrease after democratisation. Second, it does so by applying a correction methodology to the main historical source, namely the Household Budget Surveys, which leads to results challenging the prior consensus.

The literature on income distribution has undertaken many changes in the last decades. After the popularisation of Kuznets's (1955) theory about structural change and the decrease in inequality in advanced industrial countries, recent work has indicated a new upsurge ${ }^{1}$. Among its causes, globalisation and skillbiased technological change hold pre-eminent places (Atkinson 2000; Krugman 2000; Easterly 2004). The slowdown of economic growth after the oil crises and the rise of unemployment could also have played a role in certain contexts.

This phenomenon, however, cannot be analysed as a purely economic issue. On the contrary, it is connected to political developments, such as the present rise of neo-liberalism and the deep crisis in social democracy in postindustrial societies. Levy and Temin (2007) argue that the widening of

\footnotetext{
${ }^{1}$ Spain, however, did not follow this international trend until the current recession.
} 
income inequality in the United States since 1980 is largely related to the institutional context, which is shaped politically. Labour market regulation, the education system and fiscal redistribution all have strong distributive effects, as has also been underlined by Piketty (2003) for the latter.

In this context, transitions from dictatorship to democracy are expected to bring about a decrease in income inequality, as a result of the increased influence of the distributive goals of lower classes (Meltzer and Richard 1981 and related literature). However, as Acemoglu et al. (2013) note, the issue of transition might be complex and nuanced: the new regime can be «captured» by the elites and not result in fully democratic policies, and it can also lead to economic liberalisation and increased market inequalities.

The Spanish transition (1976-1982) is an interesting example for this discussion. Democratisation came when the oil crises hit the country, and the early period of the new regime was marked by industrial restructuring and international integration, as well as by an unprecedented and dramatic increase in unemployment. The intensification of structural transformation and the development of welfare-state functions brought about by the ascent of social democracy to power could have pushed the income distribution in different directions. So which force prevailed? Was democratisation a strong enough driver for equality?

Generally, studies on Spanish income inequality for the period 1970-1990 have found that differences between the poor and the rich shrank very substantially (e.g. Alcaide 2000; Ayala et al. 2006). This result is consistent with a positive impact of the political transition and the subsequent development of the welfare state in the country. This work, however, reaches different conclusions.

The main data source for the income distribution in this period are the Household Budget Surveys. These suffer from a widely known problem of under-reporting of earnings, particularly those coming from self-employment and capital, which can potentially bring about a misrepresentation of the real levels of inequality ${ }^{2}$. I address the issue with an upwards correction of household incomes by revenue sources, using both internal and external information, and ultimately adjusting the flows to the National Accounts. Similar approaches have been widespread in Latin American studies (ECLAC 1991; Engel et al. 1999; Barreix et al. 2009), and have also been recently applied by an extensive literature focusing on inequality measurement issues in several rich countries (Accardo et al. 2009; McColl et al. 2010; Neri and Zizza 2010; Fixler and Johnson 2012) ${ }^{3}$. The majority of these works, however, are

${ }^{2}$ This problem has been signalled by the literature as a reason to use tax data for the top incomes, which would make it possible to perform an upwards correction of the inequality indices (Atkinson 2007; Alvaredo 2011).

3 This orientation can be traced back to the NBER Conference on Research in Income and Wealth of 1975 (Budd and Radner 1975). At present, there is related work in progress about the United States by E. Saez, T. Piketty and G. Zucman. 
very recent and focus on the latest years available. This paper takes a step forward by adopting a historical perspective and measuring the inequality trend over several decades.

After scaling up the income data, I find inequality to be higher than in the original data, and to have experienced only a slight decrease in the transition from dictatorship to democracy. This suggests that, in Spain, the democratic transition was not sufficiently strong to impact positively on distributional dynamics. It also implies that under-reporting has to be taken into account in the study of income distribution and its changes over time. Differential rates of income concealing by source will not only mean higher inequality than that directly observed, but may also affect its trend, fundamentally in the presence of significant changes in the factorial distribution.

The rest of the paper is organised as follows. Section 2 discusses the procedures and conclusions of previous literature on the topic, while also presenting the main data source used, the Household Budget Surveys. The methodology and process of correction of the data are presented in section 3 , and the results and some of their implications are reported in section 4. Section 5 concludes.

\section{THE STORY OF PERSONAL INCOME EQUALISATION}

Literature has shown a widespread consensus on the fact that inequality decreased very substantially in Spain between the 1970s and the 1990s. This has been related to structural economic change and to an increase in the redistributive role played by the state in the second half of the period, due to democratisation.

These studies are generally derived from the Household Budget Surveys (henceforth HBSs): consumption and income investigations conducted by the National Statistical Institute (INE, from now on) more or less on a 10-year basis since $1964^{4}$. They provide information on socio-economic classes, total household disposable income and expenditure in different categories of goods and services. The detail and quantity of information have improved over time. Estimations of home consumption and imputed income from owner-occupied housing are also provided (thus indicating if the family rents or owns their house), as are the households' size and some information on their age composition. The income data always refer to disposable income, so each component is net of direct taxes: this is also the definition used throughout this paper.

There are significant differences in the results obtained from this source. Some studies use the original income data provided by the surveys, while

\footnotetext{
${ }^{4}$ It is not possible to rely on personal income tax statistics to study income distribution in the general population, given that until 1979 they covered only a very small part of it. As a depiction of top incomes, they have been used by Alvaredo and Saez (2009). Other work has relied on macroeconomic indicators (Prados de la Escosura 2008).
} 
others rely on different correction procedures, since some troubling problems are widely known to be present in the HBSs. I will first review the results based on the original data and then proceed to discuss the quality issues in the surveys. Finally, I will show the corrections proposed by previous literature.

\subsection{Working with the Raw HBS Data}

The studies which use the raw HBS data are surveyed in Table 1. They observe a significant reduction of inequality through these decades, attaining levels comparable to those of other developed European countries by 1990 . Many of these studies acknowledge the problems in the data, such as underreporting, and therefore call for caution or test for possible impacts with techniques such as trimming (Cowell et al. 1999) or a comparison with National Accounts (Oliver et al. 2001).

The values of the inequality indices vary depending on each author's methodological choices, such as the income definition, the equivalence scale applied, or the weighting unit. All these are important conceptual decisions to be made by the researcher. I deem preferable an income definition as wide as possible (TDI in the table, which includes in kind elements such as imputed owner-occupier income - but, we should remember, excludes direct taxation), and individual weighting. This last aspect may not have a large quantitative impact on the indices, but implies giving the same value in our calculations to all individuals (while weighting by households effectively means attaching less importance to those living in large families). In any case, these choices do not change the qualitative result here: a decrease in inequality along with the political transition.

Alternatively, many authors are interested in working with inequality of consumption instead of income, or along with it (e.g. Del Río and RuizCastillo 1996; Martín-Guzmán et al. 1996; Goerlich and Mas 2001; Gradín 2002; Gradín et al. 2008). They generally also find a decrease in inequality during the decades of $1970-1990^{5}$. The rationale for this approach is that, in the context of the life-cycle and permanent income theory, consumption is a better indicator of welfare. An excellent survey of the debate is provided by Gradín et al. (2008), who compare the results of using income or consumption. Morelli et al. (2015) argue that income is conceptually a better indicator,

5 Martín-Guzmán et al. (1996), for example, give a Gini of per capita expenditure of 35.7, 35.0 and 34.2 respectively for the three HBSs (this includes non-monetary items and is weighted by household). Goerlich and Mas (2001) find 32.7, 31.4 and 30.3 with total equivalised expenditure. Gradín's (2002) calculations result in 35.9, 33.2 and 31.7 (OECD's equivalence scale), which is slightly over the values he obtains for income (35.2, 32.7 and 30.6). Some works on expenditure inequality have also been carried out with the data provided by another survey, the Encuesta Continua de Presupuestos Familiares, generally obtaining lower levels; see e.g. Gradín et al. (2008) or Pijoan-Mas and Sánchez-Marcos (2010). 
TABLE 1

INCOME INEQUALITY IN STUDIES USING THE RAW HBSs

\begin{tabular}{|c|c|c|c|c|c|c|}
\hline \multirow[b]{2}{*}{ Study } & \multirow[b]{2}{*}{ Income definition $^{2}$} & \multirow[b]{2}{*}{ Equivalence scale $^{3}$} & \multirow[b]{2}{*}{ Weights $^{4}$} & \multicolumn{3}{|c|}{ Income Gini } \\
\hline & & & & 1973 & 1980 & 1990 \\
\hline \multirow[t]{2}{*}{ Ayala et al. (1996) } & MDOI & OECD & $\mathrm{H}$ & - & 33.7 & 31.2 \\
\hline & MDOI & OECD & I & - & 33.0 & 30.5 \\
\hline Martín-Guzmán et al. (1996) & TDI & per capita & $\mathrm{H}$ & 35.8 & 35.2 & 33.0 \\
\hline Cowell et al. (1999) & TDI & SR & I & - & 31.3 & 30.0 \\
\hline \multirow[t]{3}{*}{ Goerlich and Mas (2001) } & TDI & $\mathrm{B}(0.5)$ & I & 32.1 & 31.0 & 29.3 \\
\hline & TDI & No & $\mathrm{H}$ & 36.2 & 34.2 & 33.0 \\
\hline & TDI & per capita & I & 34.2 & 33.7 & 31.6 \\
\hline Oliver et al. (2001) & TDI & OECD & $\mathrm{H}$ & - & $33.1^{1}$ & 29.3 \\
\hline \multirow{3}{*}{ Ayala et al. (2006) } & MDI & $\mathrm{B}(0.5)$ & $\mathrm{H}$ & 35.3 & 33.3 & 31.7 \\
\hline & MDI & OECD & $\mathrm{H}$ & 35.4 & 33.9 & 31.7 \\
\hline & MDI & OECD mod. & $\mathrm{H}$ & 35.0 & 33.4 & 31.4 \\
\hline
\end{tabular}

Notes: ${ }^{1}$ Oliver et al. (2001)'s source is a different survey (Encuesta Continua de Presupuestos Familiares) which was initiated in 1985. The value for that year is introduced in the 1980 column in the table.

${ }^{2}$ Income definition: TDI is Total Disposable Income, MDI is Monetary Disposable Income, MDOI includes only ordinary revenues.

${ }^{3}$ Equivalence scales: SR means square root of household size, $\mathrm{B}(0.5)$ Buhmann et al. (1988)'s scale with elasticity of 0.5 , «no» means total household income is used with no adjustment, «per capita» involves dividing it by real household size.

${ }^{4}$ Weighting: I stands for individual, $\mathrm{H}$ for household.

Source: References in column 1. 
since it measures potential consumption and therefore does not lead to the confusion of need with chosen frugality (following Sen 1992), and because current consumption may not mirror permanent income in the presence of obstacles to lifetime smoothing (especially borrowing constraints) ${ }^{6}$.

The use of consumption can also arise from the acknowledgement that income is under-assessed, and therefore reported consumption would actually be closer to real income than the stated revenue amounts. Expenditure data are not free of measurement issues, such as the difficulty of capturing consumption of durable goods correctly. However, income is truly known to be under-estimated in many surveys, and remarkably in our case. I turn to this now.

\subsection{Biases in the Sources}

The quality of the HBSs data is highly uneven. There are no micro-data available for the 1964-1965 survey, so it is only possible to work with aggregate results published by the INE. In the other cases (1973-1974, 19801981 and 1990-1991) ${ }^{7}$, micro-data are available on-line. In this work, I am using the files provided by Carlos III University, which undertook a project to facilitate their usage ${ }^{8}$.

Several issues on the reliability of HBSs (and that of their counterparts in other countries) have been put forward by the literature, starting with the publications of the INE itself. As may be seen in Table 2, household surveys underestimate inequality for a number of reasons. Some of them seem more worrying than others: the exclusion of the homeless might be insurmountable, but its quantitative impact is limited. Undistributed profits can be considered as part of the economic capacity of the individuals they accrue to, but may be left aside from an annual income analysis (as is indeed most common in the literature $)^{9}$.

The remaining issues appear more troubling. Oversampling the higherincome strata (urban areas with wealthy inhabitants) would have helped to provide better estimates of income for rich families, since the variability among them is usually higher (this is a common method in modern statistics). On the other hand, non-response and under-reporting entail a likely under-representation of the rich both in quantity and income levels.

\footnotetext{
${ }^{6}$ Attanasio (1999), with cohort data from the United States and the United Kingdom, shows how the variability of disposable income over the life cycle is mirrored by that of consumption, although in a less pronounced way in the case of equivalent non-durables. Borrowing constraints have been found significant for low income households in several studies, for example Cutanda (2003).

7 The surveys always covered a 12-month period, but it did not coincide with the calendar year.

8 Please see http://www.eco.uc3m.es/investigacion/epf.html.

9 The bias associated to this exclusion would grow, however, given that National Accounts depict an increase in corporations' share of capital income with respect to that of households.
} 
TABLE 2

BIASES IN THE HOUSEHOLD BUDGET SURVEYS

\begin{tabular}{|l|l|c|}
\hline & Problem & Effect on inequality \\
\hline Universe & Excludes the homeless & - \\
\hline Income definition & Excludes undistributed profits & - \\
\hline Sampling procedure & No oversampling & - \\
\hline Non-response & Larger in dynamic urban areas & - \\
\hline Under-reporting & Larger in non-salary income & - \\
\hline
\end{tabular}

Source: Compiled with information in Garde et al. (1996).

Not correcting for these effects implies a potentially important bias. The problem is relatively common in this kind of survey, stemming from lack of accounting control in the families, hiding of income from informal activities, fear of tax inspection, and so on.

Trying to confront the issue, some statistical work was already undertaken during the 1970s. At least part of the unit non-response bias is corrected by the INE with the scaling-up factors provided with the results, which give higher population weights to observations in strata where unit non-response was more acute ${ }^{10}$. However, under-reporting clearly remains an issue ${ }^{11}$. A simple comparison of the data on total income and total expenditure (plus net savings) tells us that something is wrong: only 30-40 per cent of the households spend less than their yearly income, while around 10 per cent would consume more than twice its level (Table 3; see also the distribution disaggregated by decile in Appendix A).

Certainly, not all families in a given year spend less than they earn, but the high ratios in the table seem implausible, especially given that total net household savings in those years were positive, according to the Spanish National Accounts.

In fact, another possible evidence of under-reporting is a comparison with National Accounts data, which are normally taken as a more reliable

${ }^{10}$ Unit non-response is total lack of answer from one selected household, due to refusal or inability to contact it; it is different from item non-response, which arises when one household participates in the survey but fails to provide answers to selected questions. The re-weighting procedure does not eliminate the whole problem, as it can be argued for example that non-response correction should also take into account the income level of households' strata, which affects the probability of response, as suggested by Mistiaen and Ravallion (2003). Pérez-Duarte et al. (2010), however, show that for the Finnish wealth survey non-response bias was not substantially reduced after applying more refined re-weightings and calibrations using further variables.

11 It has to be kept in mind that these are not tax data, so the term under-reporting does not equal tax base fraud: it could be related to evasion, but also to lack of adequate accountancy, mistakes and forgetfulness, or errors in calculating yearly totals from the questions in the surveys. 
TABLE 3

HOUSEHOLDS AND BUDGET CONSTRAINT: DISTRIBUTION ACCORDING TO THE RATIO (EXPENDITURE + NET SAVINGS)/INCOME

\begin{tabular}{|l|c|c|c|c|c|}
\hline & $\mathbf{0 - 1}(\mathbf{\%})$ & $\mathbf{1 - 2}(\boldsymbol{\%})$ & $\mathbf{2 - 4}(\boldsymbol{\%})$ & $\mathbf{> 4}(\boldsymbol{\%})$ & Total (\%) \\
\hline $1973-1974$ & 30.8 & 57.4 & 10.7 & 1.1 & 100 \\
\hline $1980-1981$ & 37.2 & 53.5 & 8.4 & 0.8 & 100 \\
\hline $1990-1991$ & 41.9 & 48.5 & 8.8 & 0.8 & 100 \\
\hline
\end{tabular}

Notes: Households in the first column spend within their budget constraint. A ratio of 2, for example, means that the family reported having spent twice as much as its yearly income.

Source: Calculated from Household Budget Surveys.

TABLE 4

DISPOSABLE INCOME IN HBSS AND NATIONAL ACCOUNTS (MILLIONS OF NOMINAL PESETAS)

\begin{tabular}{|l|c|c|c|}
\hline & HBSs (1) & Nat. Acc. (2) & $\mathbf{( 1 ) / ( 2 ) ( \% )}$ \\
\hline 1973 & $2,209,839$ & $3,099,302$ & 65.5 \\
\hline 1980 & $7,703,772$ & $11,049,326$ & 69.7 \\
\hline 1990 & $25,079,849$ & $33,387,093$ & 75.1 \\
\hline
\end{tabular}

Sources: Author's calculations and Pena Trapero (1996).

source for the aggregates. Disposable income totals are contrasted in Table 4 (a disaggregated comparison can be found in the tables of Appendix C). Disposable incomes in the surveys are only around 70 per cent of those estimated in national accounting for the household sector, which reinforces our suspicion that in the HBSs they are under-assessed to a considerable extent. The fact that this problem affects richer areas and non-salary income to a greater degree (as stated by, e.g., Alcaide and Alcaide 1974 and Sanz 1995) should warn us against the use of these data without enough criticism. The under-estimation of incomes in the surveys seems more acute in the 1970s than in 1990, which could indicate an improvement in the accuracy of the source and therefore a non-homogeneous bias over time - thus affecting inter-temporal comparisons ${ }^{12}$.

12 Other household surveys have been contrasted with the magnitudes from National Accounts with similar results. Pou and Alegre (2002) made the comparison for the Encuesta Continua de Presupuestos Familiares, a rotating panel stretching from 1985 to 1996, and found that the ratio in gross terms was around 62-69 per cent, with a slight improvement over the period. (This ratio is not directly comparable to those given in the last column of Table 4, which are obtained from the net magnitudes. In the case of the HBSs, the corresponding gross values would be $66.8,74.7$ and 80.2 


\subsection{Literature with Correction of HBSs}

The problems surveyed in the previous subsection were known by both the INE and the research community at the time. As a result, some corrections were attempted in the data. Table 5 displays the original distribution from the HBSs, together with the main adjusted estimates available.

The original distributions show a constant increase in the shares of the bottom five deciles, together with a decrease in the part accruing to the top (deciles 9-10). The Gini index corresponds to that given by Goerlich and Mas (2001) in their second row in Table 1. According to these data, the period of the democratic transition was very positive for the Spanish poor and middle classes.

The other columns in the table present distributions corrected for underreporting with different procedures. J. Alcaide was the first researcher to tackle the issue, contemporaneously to the surveys. In Alcaide (2000) he showed an abrupt decrease in disposable income inequality starting at some point between 1973 and 1980, and continuing with less intensity in the following years. His corrections on the HBSs are based on the difference between total income and total expenditure data, taking the latter as more reliable (since they adjust better to the National Accounts and households may have felt less reluctant to report them). His first step thus consisted of an upwards adjustment of income to expenditure, with data aggregated by socio-economic groups, and he later scaled-up the corrected income figures to National Accounts ${ }^{13}$. These results have been widely accepted since. Table 5 shows that his procedure provided higher inequality figures than the raw HBSs data. Because the difference is much larger for 1973-1974, Alcaide's calculations depict a more powerful retreat of inequality during the years of the political transition than in the following decade. Estruch (1996) used a very similar methodology, applying it to the 1990-1991 data, in his work on public spending.

Alternatively, it can be accepted as economically normal that some households consume above their yearly income, up to a certain extent. Such an approach was taken by the INE's study of the 1973-1974 survey, for the volume La Renta Nacional y su Distribución 1976 (Instituto Nacional de Estadistica 1977): they accepted as «honest» those households where the

\footnotetext{
(footnote continued)

per cent for the 3 years respectively: the ECPF thus appears more unreliable for the study of income inequality than the benchmark year surveys I am using here.) Andrés and Mercader-Prats (2001) engaged in similar calculations with the 1994 European Community Household Panel. They present ratios for the different income sources which show the high reliability of wages and salaries data, and the difficulties with incomes from self-employment and capital. This result coincides with our further exploration of HBSs in section 3.

13 The methodology is best explained in Alcaide and Alcaide (1974), where there is reference to other sources used, such as the INE's wage surveys and a Pareto simulation in the upper tail of the distribution.
} 
TABLE 5

DISTRIBUTION OF DISPOSABLE INCOME ACROSS DECILES (PERCENTAGE OVER TOTAL) ${ }^{2}$

\begin{tabular}{|l|c|c|c|c|c|c|c|c|c|c|c|}
\hline & \multicolumn{3}{|c|}{ Original HBSs } & \multicolumn{3}{c|}{ Alcaide $^{\mathbf{1}}$} & INE & Estruch & \multicolumn{3}{c|}{ Pena Trapero et al. } \\
\cline { 2 - 12 } & $\begin{array}{c}\mathbf{1 9 7 3 -} \\
\mathbf{1 9 7 4}\end{array}$ & $\begin{array}{c}\mathbf{1 9 8 0 -} \\
\mathbf{1 9 8 1}\end{array}$ & $\begin{array}{c}\mathbf{1 9 9 0 -} \\
\mathbf{1 9 9 1}\end{array}$ & $\begin{array}{c}\mathbf{1 9 7 3 -} \\
\mathbf{1 9 7 4}\end{array}$ & $\begin{array}{c}\mathbf{1 9 8 0} \mathbf{1 9 8 1} \\
\mathbf{1 9 9 0 -}\end{array}$ & $\begin{array}{c}\mathbf{1 9 7 3 -} \\
\mathbf{1 9 9 1}\end{array}$ & $\begin{array}{c}\mathbf{1 9 9 0}- \\
\mathbf{1 9 9 1}\end{array}$ & $\begin{array}{c}\mathbf{1 9 7 3 -} \\
\mathbf{1 9 7 4}\end{array}$ & $\begin{array}{c}\mathbf{1 9 8 0} \\
\mathbf{1 9 8 1}\end{array}$ & $\begin{array}{c}\mathbf{1 9 9 0} \\
\mathbf{1 9 9 1}\end{array}$ \\
\hline Decile 1 & 2.1 & 2.5 & 2.7 & 1.8 & 2.4 & 2.7 & 1.8 & 3.9 & 2.6 & 2.6 & 2.8 \\
\hline Decile 2 & 3.9 & 4.1 & 4.3 & 3.2 & 4.0 & 3.5 & 3.1 & 4.4 & 4.0 & 4.2 & 4.5 \\
\hline Decile 3 & 5.3 & 5.4 & 5.6 & 4.5 & 5.2 & 5.2 & 4.2 & 5.9 & 5.1 & 5.3 & 5.6 \\
\hline Decile 4 & 6.5 & 6.7 & 6.8 & 5.1 & 6.3 & 6.3 & 5.3 & 8.1 & 6.1 & 6.3 & 6.5 \\
\hline Decile 5 & 7.8 & 7.9 & 8.0 & 6.3 & 7.4 & 7.7 & 6.5 & 9.9 & 7.1 & 7.3 & 7.6 \\
\hline Decile 6 & 9.1 & 9.3 & 9.2 & 8.0 & 8.8 & 8.5 & 7.9 & 10.0 & 8.3 & 8.5 & 8.7 \\
\hline Decile 7 & 10.6 & 10.7 & 10.7 & 9.1 & 10.0 & 9.8 & 9.8 & 10.3 & 9.8 & 9.9 & 10.1 \\
\hline Decile 8 & 12.5 & 12.6 & 12.5 & 10.1 & 11.5 & 11.8 & 12.6 & 12.2 & 11.8 & 11.8 & 11.9 \\
\hline Decile 9 & 15.6 & 15.6 & 15.5 & 12.4 & 15.1 & 15.1 & 16.9 & 15.9 & 15.0 & 15.0 & 14.9 \\
\hline Decile 10 & 26.8 & 25.4 & 24.7 & 39.6 & 29.2 & 28.4 & 31.9 & 19.4 & 30.8 & 29.4 & 27.4 \\
\hline Gini & 36.2 & 34.3 & 33.0 & 44.6 & 36.3 & 34.7 & 42.5 & 29.3 & 38.7 & 37.6 & 35.0 \\
\hline
\end{tabular}

Notes: ${ }^{1}$ Alcaide's calculations for 1990 are based on a different survey, the ECPF, and therefore not strictly comparable to those of the HBS analysed here. ${ }^{2}$ The unit of analysis is the household and the income definition used corresponds to total disposable income (not per capita, not equivalised); except for Pena Trapero's study, where it is income per capita. The Gini indices given in the cited studies are calculated out of the aggregated data, and thus underestimated with respect to those obtainable from micro-data.

Sources: Calculated on the basis of HBSs, Alcaide (2000), Instituto Nacional de Estadística (1977), Estruch (1996) and Pena Trapero (1996). 
difference between total expenditure (plus net savings) and income was not larger than 5 per cent ${ }^{14}$. With those, a log-log relationship was estimated between consumption and income and used to correct the under-reported incomes. The result was also a more unequal distribution. The authors themselves considered it as a lower cap on inequality, since «honest» families were found mostly in the poorer deciles: if expenditure-income elasticity is not constant but decreasing, the concentration of income would be greater than estimated.

A similar procedure was applied by Pena Trapero (1996). They first obtained under-reporting correction factors by socio-economic categories, again derived from the relationship of declared income with consumption (ranging from 1.63 to 1.11). However, these were not applied directly on the total income of the household: 1.06 was assigned to salaries and 1.03 to public benefits, following the results in Díaz and Fernández (1993); which implies that the correction factors for other income sources resulted higher as a consequence. In a second step, they applied a uniform adjustment to the National Accounts ${ }^{15}$. Their result is also higher inequality than in the original surveys, with a lower reduction over time than the figure according to Alcaide ${ }^{16}$.

In the next section I present an alternative procedure to deal with income under-reporting, which leads to different conclusions.

\section{ADJUSTING HOUSEHOLD SURVEYS}

My methodology is similar to that of Alcaide and Pena Trapero in the basic intuitions; namely using income-expenditure discrepancy and scalingup to National Accounts. However, the specific calculations differ, and so do the results. I first follow Pissarides and Weber (1989) and Martínez-López (2012) to obtain the relative level of under-reporting of the self-employed, using only information from the surveys. Then I resort to comparison with National Accounts, but instead of employing the aggregate disposable income I make separate contrasts for the different sources of household revenue, as suggested by Oliver (1997). This makes it possible to obtain particular adjustment factors and therefore a more realistic view of the distribution.

14 Argimón et al. (1987), for their study on indirect taxation in 1980, followed the same assumption. They used, however, provincial-level data, since the micro-data were not yet available at the time of their work, and I have not therefore included their estimation in the table.

15 Pena's procedure was followed with slight modifications in Marchante Mera et al. (2002). The focus of this study, however, is not income inequality but consumption and savings by age group, which is why it is not surveyed here.

${ }_{16}$ It should be noted that the reported distribution in Pena Trapero (1996) is of income per capita, so the comparison with the other columns is not straightforward. 


\subsection{Relative Under-Reporting of the Self-Employed}

It is widely believed that the self-employed under-report their incomes both in tax assessments and income surveys. Pissarides and Weber (1989) were the first to suggest an estimation of this concealing of incomes by means of contrasting their expenditure levels (on food) with those of wageearners in household surveys. Their idea was based on the basic assumptions of accurate reporting of: (a) the incomes of wage-earners and (b) the food expenditures of both kinds of households. The intuition is that wage-earners can more easily know their exact income (because of its regularity) and also have fewer tax-fraud incentives to hide it in a survey (since they have less capacity to evade anyway, given withholding at source). Expenditures are generally known to be better declared than income in household surveys, and especially in the case of food, with ratios near $90-100$ per cent with respect to National Accounts.

Pissarides and Weber (1989) concluded for Britain in 1982 that incomes reported by the self-employed should be multiplied by a factor of 1.55 to obtain their true earnings. After them, a wide literature has undertaken similar calculations for other countries and time-periods, with some further methodological contributions (Lyssiotou et al. 2004; Johansson 2005; Engström and Holmlund 2009; Tedds 2010; Martínez-López 2012; Hurst et al. 2014). Here I follow Engström and Holmlund (2009), who calculated a factor of 1.30 for Sweden around the year 2000, and Martínez-López (2012), who estimated 1.25 for Spain in 2006-2009. Martínez-López stressed that this coefficient was relative to the wage-earners' own under-reporting rate something which is important in the Spanish case and in a historical analysis, where salaried workers might not be completely reliable.

The procedure is based on the estimation of an Engel curve with the following form:

$$
\ln F=\alpha+\beta \ln Y^{D}+\gamma \mathrm{SE}+\delta \mathrm{Z}+u
$$

where $F$ being declared food expenditure, $\alpha$ the subsistence level, $Y^{D}$ total declared income, $S E$ a dummy for self-employed households (defined as those where at least the household head or the spouse is so), $\mathrm{Z}$ a vector of control variables (family size, town size, and so on), and $u$ the error term. $\gamma$ is expected to be positive, implying an apparent higher consumption of food among the self-employed, which is interpreted as income under-reporting. The idea can be seen in Figure 1, where $\gamma$ would be the vertical difference between both regression lines, $\beta$ the slope (estimated elasticity) and $\ln F^{*}$ the log of reported food consumption by two households with the same real incomes $Y^{R}$, but different reported incomes $Y^{D}$. 
FIGURE 1

PISSARIDES-WEBER'S MODEL

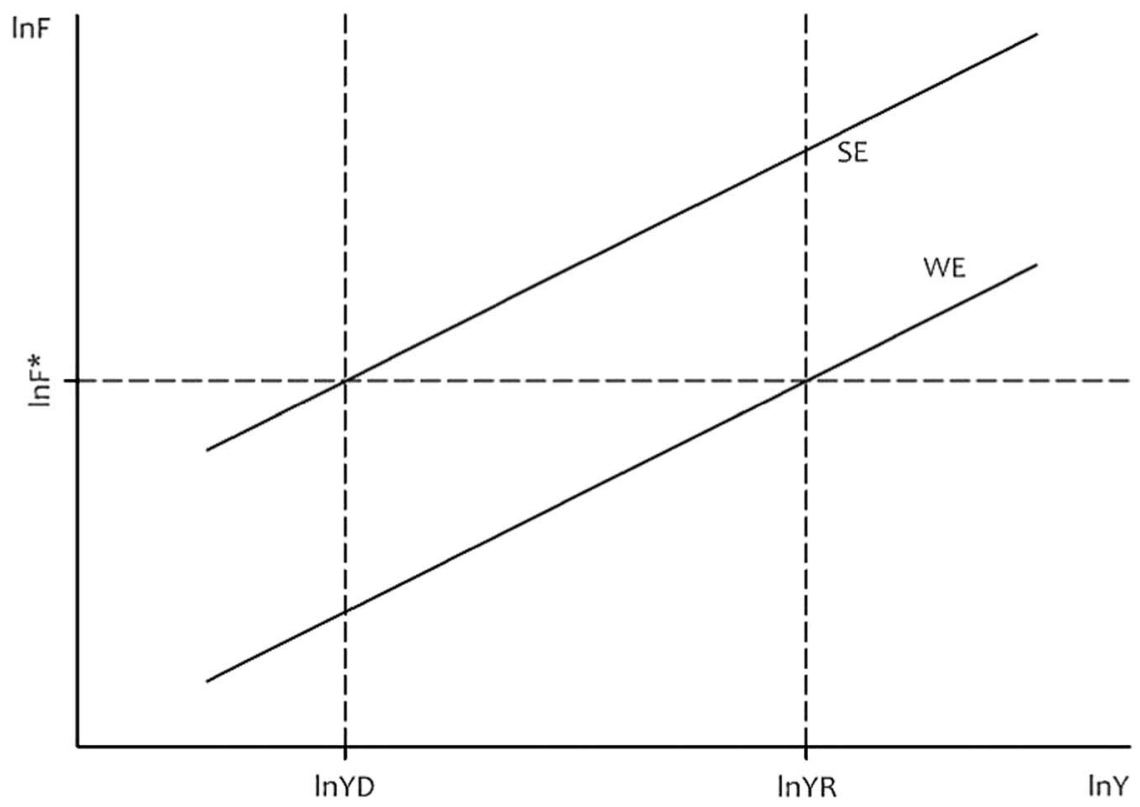

Source: Adapted from Engström and Holmlund (2009).

The difference between real income $Y^{R}$ and declared income $Y^{D}$ (in logs, horizontal distance between both vertical lines in the graph) is given by:

$$
\ln Y^{R}-\ln Y^{D}=\gamma / \beta
$$

because of the formula to calculate the slope of the regression line in Figure $1\left(\beta=\gamma /\left(\ln Y^{R}-\ln Y^{D}\right)\right)$. Then we can further obtain:

$$
Y^{R} / Y^{D}=\exp (\gamma / \beta)=k
$$

where $k$ being the factor by which the self-employed person's declared income should be multiplied in order to obtain their real income (under the assumption that the wage-earners' reporting is correct - i.e. relative to it).

Food expenditure is used as the dependent variable for various reasons: it is one of the most accurately reported expenditures in the surveys (in terms of the adjustment with National Accounts of total resulting consumption), and we can safely assume that it is less affected by preferences than other 
goods. Rural households are excluded from the estimation, since they might obtain a significant part of their food supply outside the market and not report it correctly. The variable $F$ is defined as expenditure on food (excluding alcohol and tobacco) plus foodstuff self-supply and free meals provided by companies to their employees. It is thus supposed to capture total food consumption, except for meals at restaurants and similar establishments.

In order to make the results more robust, I have made an alternative estimation with energy consumption as the dependent variable. In the surveys, this item was requested as the last bill, so it could be easier to report correctly, without the need to note down and control purchases associated with food expenditure. It is also less affected by the issue of eating at the firm, outside home and so on. The energy consumption reported is only that of the household as a family: that is explicitly excluding expenditures associated with unincorporated businesses.

The results of the estimation are shown in Table 6. Taking the average $k$ derived from both models, for each year, the self-employed would under-report their incomes by around 14-20 per cent more than the recipients of salary income ${ }^{17}$. This result could be applied directly to the data, estimating the effects of the under-reporting of the self-employed independently from the other issues identified (see Appendix B). The impact, however, is limited. In this paper, I prefer to retain this coefficient underlining its relative nature, to integrate it in the next exercise.

\subsection{Scaling-Up to National Accounts}

The other source of correction is external information: a comparison of the totals for each type of income obtained from the surveys with those in National Accounts, which are considered more reliable for the aggregate results, and supposed to capture at least a part of the black economy. This micro-macro contrast of aggregates is a common and desirable practice, as stated by the Canberra Expert Group (2011). The step is common in the analysis of survey data in other countries, as can be seen, for instance, in ECLAC's reports, Engel et al. (1999) and Barreix et al. (2009).

Complete income accounts for households are available in the Spanish National Accounts since 1980 (the different economic flows are disaggregated by sectors, one of which is the households, together with private non-profit institutions). Data for 1973 are taken from Pena Trapero (1996), with the exception of capital incomes, which have been

17 My results are slightly below Martínez-López's (2012) estimation for later years. However, this should not be directly interpreted as an increase in under-reporting, since the factor is relative to the wage-earners' behaviour. A constant reporting rate of the self-employed with increased compliance of the salaried households would also be consistent with the results. 
TABLE 6

REGRESSION FOR RELATIVE UNDER-REPORTING OF THE SELF-EMPLOYED

\begin{tabular}{|c|c|c|c|c|c|c|}
\hline & \multicolumn{2}{|c|}{1973} & \multicolumn{2}{|c|}{1980} & \multicolumn{2}{|c|}{1990} \\
\hline & (1) & (2) & (3) & (4) & (5) & (6) \\
\hline Dep. var. & $\ln ($ Food $)$ & $\ln ($ Energy) & $\ln ($ Food $)$ & $\ln$ (Energy) & $\ln ($ Food $)$ & $\ln$ (Energy) \\
\hline $\ln Y$ & $0.268(0.00841)^{* * *}$ & $0.438(0.0106)^{* * * *}$ & $0.207(0.00960)^{* * *}$ & $0.368(0.0124)^{* * *}$ & $0.167(0.0100)^{* * * *}$ & $0.280(0.0137)^{* * *}$ \\
\hline SE & $0.0407(0.00999)^{* * *}$ & $0.102(0.0135)^{* * *}$ & $0.0446(0.0107)^{* * * *}$ & $0.0892(0.0145)^{* * *}$ & $0.0185(0.0109)^{*}$ & $0.0558(0.0148)^{* * * *}$ \\
\hline Observations & 14,442 & 14,297 & 12,624 & 12,619 & 10,360 & 10,242 \\
\hline$R^{2}$ & 0.371 & 0.236 & 0.315 & 0.200 & 0.312 & 0.133 \\
\hline$k$ & 1.16 & 1.26 & 1.24 & 1.27 & 1.12 & 1.22 \\
\hline Average $k$ & \multicolumn{2}{|c|}{1.21} & \multicolumn{2}{|c|}{1.26} & \multicolumn{2}{|c|}{1.17} \\
\hline
\end{tabular}

Notes: Robust standard errors in parentheses. ${ }^{*} * * P<0.01, * * P<0.05, * P<0.1$.

Controls include: household size, age of household head, dummies for municipality size and survey seasonality, meals in restaurants in columns (1), (3) and (5), a dummy for cold climate in columns (2), (4) and (6), and a constant.

Source: See text. 
approximated using the percentage of dividend and interest income in "incomes from property and enterprise» in the household sector in 1969 and 1980 (the two closest available years) ${ }^{18}$.

There are some coverage differences between the surveys and the National Accounts data: namely, in the latter, households appear aggregated with Private Non-Profit Institutions, and they also include people living in collective arrangements (e.g. retirement homes), who are not present in the surveys. For an extensive discussion, see Sanz (1995). These differences are considered minor and not dealt with here ${ }^{19}$. The adjustment procedure needs to take into account that Household Surveys provide incomes net of taxes, while the figures in National Accounts are gross. The corresponding taxes have therefore been subtracted from the latter before calculating the relationship between magnitudes. Imputed incomes are not corrected, since they do not mostly derive from the respondents' answers but were estimated by the INE; hence, they are also extracted a priori from both sources ${ }^{20}$. Scaling-up factors for each source of income have been calculated with the following formula:

$$
m_{i}=\left(X_{i ; \mathrm{NA}}-I_{i}-T_{i}\right) /\left(X_{i ; \mathrm{HBS}}-I_{i}\right)
$$

with $X_{i \text {;A }}$ meaning the gross amount in National Accounts, $I_{i}$ the imputed (non-monetary) incomes in category $i$ if they exist, $T_{i}$ the associated taxes, and $X_{i ; \text { HBS }}$ the net amount given by the Household Budget Survey. See Table 7 for the correspondence between magnitudes in both sources.

The general procedure, however, is modified for the cases of Net Operating Surplus (NOS) and Transfers. NOS includes self-employment monetary income, self-employment imputed income (not corrected) and income from real estate rentals. A total adjustment to National Accounts would be incorrect, since these include undistributed profits of unincorporated enterprises, which are not present in the surveys (see section 2.2): the procedure applied here yields a difference of around 20 per cent under total adjustment. It is based on the factor for self-employment obtained thanks to the Pissarides-Weber regressions in subsection 3.1: $m_{\mathrm{SE}}$ is the product of the previously estimated $k$ and the factor for Labour income (since the equation

18 In Pena and Callealta (1996), capital incomes seem to be underestimated. I have thus used this information provided in the National Accounts publications of the pre-1970 base (where only some household flows are present).

19 There is an additional problem with interest income, which is defined in the surveys in net terms (interest incomes received minus interests paid for loans). This is consistent with an economic concept of yearly income, but not with the distribution of gross revenues of this kind across households. This is important if we wished to extrapolate to a fiscal concept, where only certain interest payments are deductible.

20 These are non-monetary flows accruing to households, related either to wage-earning activities (in-kind compensation and meals at the workplace) or to self-employment (home consumption and housing services in owner-occupied housing). 
TABLE 7

MATCHING HOUSEHOLD SURVEYS WITH NATIONAL ACCOUNTS

\begin{tabular}{|l|l|l|}
\hline Household surveys (net) & Direct taxes & $\begin{array}{l}\text { National accounts } \\
\text { (gross) }\end{array}$ \\
\hline $\begin{array}{c}\text { Self-employment } \\
\text { monetary income } \\
\text { Income from real estate } \\
\text { rentals } \\
\begin{array}{c}\text { Self-employment } \\
\text { imputed income }\end{array}\end{array}$ & $\begin{array}{c}\text { Self-employed social } \\
\text { contributions } \\
\text { Real estate tax }(80 \%) \\
\text { Income tax from mixed income }\end{array}$ & $\begin{array}{l}\text { Net Operating } \\
\text { Surplus }\end{array}$ \\
\hline $\begin{array}{l}\text { Wages and salaries } \\
\text { Employment imputed } \\
\text { income }\end{array}$ & $\begin{array}{c}\text { Income tax from employment } \\
\text { income } \\
\text { Workers' and employers' social } \\
\text { contributions }\end{array}$ & $\begin{array}{c}\text { Workers' } \\
\text { Remuneration }\end{array}$ \\
\hline $\begin{array}{c}\text { Capital income } \\
\text { Income tax from capital income }\end{array}$ & $\begin{array}{l}\text { Interests } \\
\text { Land rents } \\
\text { Dividends }\end{array}$ \\
\hline $\begin{array}{l}\text { Social benefits } \\
\text { Private transfers }\end{array}$ & $\begin{array}{c}\text { Social contributions from the } \\
\text { unemployed }\end{array}$ & $\begin{array}{l}\text { Social benefits } \\
\text { Private transfers } \\
\text { Insurance } \\
\text { compensation }\end{array}$ \\
\hline
\end{tabular}

Sources: Compiled with information based on Sanz (1995) and Pena Trapero (1996).

yielded under-estimation relative to wage-earners). The same coefficient has been applied to rental incomes, which form part of the same category in National Accounts ${ }^{21}$.

Regarding transfers, from the surveys of 1973 and 1980 it is only possible to obtain a joint correction factor for the total (which includes social benefits together with assorted private flows). However, applying this number to all households equally would underestimate inequality because benefits are better reported than the rest of transfers, and both kinds of revenue have very distinct distributions (as shown by the separate estimates for 1990). To account for this problem, I have used a different correction factor for each decile, based on the results in 1990. Since for this year the survey provides both variables, it is possible to obtain a different «general transfer factor» (total corrected transfers/total reported transfers) in each decile, the variation of which responds to the composition between private and public ones. The changing relation of this factor with the total $m_{\mathrm{TR}}$ (1.65 in 1990) is used to generate variation in the factors to apply in

\footnotetext{
${ }^{21}$ Income from real estate rentals is in fact only available separately for 1990.
} 
TABLE 8

CORRECTION FACTORS BY SOURCES OF INCOME

\begin{tabular}{|l|l|l|l|}
\hline & $\mathbf{1 9 7 3}$ & $\mathbf{1 9 8 0}$ & $\mathbf{1 9 9 0}$ \\
\hline Wages and salaries & 1.35 & 1.19 & 1.12 \\
\hline Self-employment and rental income & 1.63 & 1.51 & 1.31 \\
\hline Capital income & 4.35 & 3.40 & 6.85 \\
\hline Transfers & \multirow{2}{*}{2.51} & 2.05 & 4.02 \\
\cline { 1 - 1 } Social benefits & & & 1.43 \\
\hline
\end{tabular}

Notes: The table displays the factors $m_{i}$, obtained with expression (4), which serve to scale-up the income data to the totals in National Accounts.

Source: See text.

1980 and 1973. This means that the correction factor of transfers increases with income ${ }^{22}$.

The resulting scaling-up factors $m_{i}$ are shown in Table 8. As can be seen, they tend to decline over time, showing what seems to be the increasing reliability of the surveys.

However, this is not the case with capital income, which has the highest estimated factors (together with private transfers). This may be a reflection of structural and regulatory change. A decrease in capital income concentration could be accompanied by growing non-reporting: a rising number of households receiving small quantities of capital income and neglecting to include them in the surveys' questionnaires ${ }^{23}$. On the other hand, the increase in the associated tax burden and financial sophistication could have implied increased covering-up of such incomes ${ }^{24}$.

22 Obviously, such a procedure is not completely accurate, since the distribution of both kinds of transfers, and especially public benefits, may have changed over the period. It is however preferred to applying a single factor to all households. Alternative estimations are shown in Appendix E.

23 This source of misrepresentation of incomes in HBSs is dealt with in Engel et al. (1999) with a random imputation procedure (by deciles), the effect of which would presumably be a slight decrease in measured inequality. However, this choice is not taken here because it would be necessary to establish first what share of total misrepresentation corresponds to each problem (under-reporting vs. non-reporting).

24 Another possible explanation for the rise in $m$ would be that the total reference gross magnitudes used in 1973 and 1980 are underestimated, but it seems unlikely. An examination of the factor shares shows that the participation of capital income in household revenue increased during the decades considered here, from 5.5 in 1973 to 6.2 in 1980 and 10 per cent in 1990 . The accounts for both households and non-financial enterprises show a similar trend. However, it is possible that the data for 1973 reflect an extraordinary, circumstantial situation, since wage remuneration was increasing strongly in national income during the first half of the 1970s and profits were decreasing. The 1980 data can also be thought of as depicting an economy with low profits, given the context of crisis. 
TABLE 9

CORRECTION FACTORS BY DECILES (MEAN FACTOR APPLIED-WEIGHTED AVERAGE)

\begin{tabular}{|l|l|l|l|}
\hline & $\mathbf{1 9 7 3}$ & $\mathbf{1 9 8 0}$ & $\mathbf{1 9 9 0}$ \\
\hline Decile 1 & 1.73 & 1.50 & 1.33 \\
\hline Decile 2 & 1.59 & 1.51 & 1.28 \\
\hline Decile 3 & 1.54 & 1.40 & 1.26 \\
\hline Decile 4 & 1.51 & 1.38 & 1.27 \\
\hline Decile 5 & 1.49 & 1.37 & 1.25 \\
\hline Decile 6 & 1.48 & 1.36 & 1.27 \\
\hline Decile 7 & 1.49 & 1.37 & 1.28 \\
\hline Decile 8 & 1.51 & 1.40 & 1.29 \\
\hline Decile 9 & 1.57 & 1.40 & 1.33 \\
\hline Decile 10 & 1.75 & 1.45 & 1.55 \\
\hline Top 1\% & 2.06 & 1.69 & 2.40 \\
\hline Total & 1.57 & 1.41 & 1.31 \\
\hline
\end{tabular}

Note: Deciles are built on the corrected resulting disposable income.

Source: See text.

The application of these coefficients to each type of income, at the microdata level, yields a different compound correction factor to each household, as well as to every possible socio-economic sub-group, by composition effect. Table 9 shows the resulting factors by deciles. The profiles have a J-shape, being lower at the middle part of the distribution and attaining the highest values at the very top.

\section{THE EVOLUTION OF THE SPANISH INCOME DISTRIBUTION (1973-1990): AN ALTERNATIVE PICTURE}

The final outcome of the correction is a set of higher inequality estimates, compared with those resulting from the original INE data, as was originally expected. Table 10 displays the Gini indices obtained, following two different calculations. The first row shows inequality of disposable income across households, with no adjustment for household size and using them as the unit of analysis (thus giving the same importance in the estimation to a 
TABLE 10

SPANISH INCOME INEQUALITY (1973-1990) IN THE SCALED-UP DATA (GINI INDEX)

\begin{tabular}{|l|l|l|l|}
\hline & $\mathbf{1 9 7 3}$ & $\mathbf{1 9 8 0}$ & $\mathbf{1 9 9 0}$ \\
\hline Disposable total income (households) & 36.8 & 33.5 & 34.8 \\
\hline Disposable equivalent income (individuals) & 34.6 & 32.6 & 33.0 \\
\hline
\end{tabular}

Note: Equivalent incomes are obtained using the OECD scale.

Source: Calculated from HBSs.

one-member household and to a six-member one); the second uses equivalent income and individual weights (i.e. each person is assigned the equivalent per capita income of its household and has the same importance in the estimation). The latter approach provides a better measure of inequality between individuals, but it requires some assumptions about the distribution of resources within the family and economies of scale in consumption ${ }^{25}$. Unsurprisingly, inequality is lower between individuals than between households, because larger families tend to have higher aggregate incomes ${ }^{26}$.

As can be seen, the correction of under-reporting also implies a change in the observed trend of inequality. While the unadjusted data and the corrections from previous literature reviewed earlier showed an abrupt improvement in the distribution over time, the new corrected incomes show a much smaller change over these decades (around 1.5 Gini points). We can thus talk about considerable persistence in inequality. This result contrasts with most of the literature presented in section 2 , but is not necessarily at odds with studies based on tax or macroeconomic data, which are reviewed in Appendix F.

\subsection{Relative Inequality and its Composition}

The inspection of decile shares based on the corrected disposable income data allows a deeper analysis of the evolution of income distribution. In Table 11 inequality among households is shown to have been quite stable

\footnotetext{
25 It is assumed that all members of a household are entitled to the same level of material wellbeing (that they share their income equally). Regarding the elasticity of «needs» to household size and composition, here I use the OECD scale, which attaches value 1 to the first adult, 0.7 to the subsequent ones and 0.5 to the minors in the household (up to 14 years old). The choice is consistent with empirical results based on Spanish data (Bosch-Domenech 1991; Duclos and Mercader-Prats 1999; Labeaga et al. 2004).

26 The general result of higher inequality after scaling-up is not present in the 1980 data with household weighting (first row): in this case, the Gini index for adjusted incomes is actually slightly lower than the original one. This should be attributed to the approximate methods and the plausible under-adjustment in rental incomes and interest incomes. In any case, the main point of interest is inequality between individuals.
} 
TABLE 11

SHARES OF DISPOSABLE INCOME ACROSS DECILES (PERCENTAGE)

\begin{tabular}{|l|c|c|c|c|c|c|}
\hline & \multicolumn{3}{|c|}{ Total income-households } & \multicolumn{2}{c|}{ Equivalent income-individuals } \\
\cline { 2 - 7 } & $\mathbf{1 9 7 3}$ & $\mathbf{1 9 8 0}$ & $\mathbf{1 9 9 0}$ & $\mathbf{1 9 7 3}$ & $\mathbf{1 9 8 0}$ & $\mathbf{1 9 9 0}$ \\
\hline Decile 1 & 2.38 & 2.84 & 2.79 & 3.01 & 3.00 & 3.22 \\
\hline Decile 2 & 4.09 & 4.45 & 4.33 & 4.51 & 4.74 & 4.83 \\
\hline Decile 3 & 5.23 & 5.60 & 5.49 & 5.55 & 5.85 & 5.84 \\
\hline Decile 4 & 6.31 & 6.71 & 6.52 & 6.52 & 6.82 & 6.74 \\
\hline Decile 5 & 7.42 & 7.81 & 7.61 & 7.50 & 7.82 & 7.72 \\
\hline Decile 6 & 8.64 & 8.98 & 8.84 & 8.62 & 8.90 & 8.72 \\
\hline Decile 7 & 10.14 & 10.41 & 10.23 & 9.98 & 10.23 & 9.95 \\
\hline Decile 8 & 12.15 & 12.25 & 12.06 & 11.88 & 12.04 & 11.65 \\
\hline Decile 9 & 15.41 & 15.14 & 15.02 & 14.73 & 14.78 & 14.45 \\
\hline Decile 10 & 28.23 & 25.80 & 27.13 & 27.69 & 25.80 & 26.87 \\
\hline Top 1\% & 6.47 & 6.03 & 7.15 & 6.65 & 6.14 & 7.30 \\
\hline
\end{tabular}

Note: Equivalent incomes are obtained using the OECD scale.

Source: See text.

over these decades (consistent with the Gini indices in the first row of Table 10). Interpersonal inequality, which is approached by the distribution of equivalent income in columns 5-7, is slightly lower. In any case, the absence of a clear trend remains. The bottom-half deciles increased their share, but the changes are small and erratic.

It is nonetheless most likely that the roots of inequality in the economy changed during these decades. The capital-labour ratio had been decreasing in the last years of the dictatorship as a short-term response to the crisis, and could have increased again later because of liberalisation. Most advanced industrial economies have experienced a recent increase in wage and salaries dispersion. These trends, together with the increase in unemployment, could have counteracted to some extent the equalising force of public benefits expansion and the introduction of progressivity in the tax system ${ }^{27}$.

27 The tax reform initiated in 1977 is an important cornerstone in the political transition, since it meant basing the collection of taxes on the principles of equity and efficiency; the former meaning progressive taxation. The implementation of the new system, however, does not seem to have been very successful in this aspect (Torregrosa n.d.). On the other hand, it should be noted that our three observations are to a certain extent also a result of short-term fluctuations: 1973 was the 
FIGURE 2

COMPOSITION OF DISPOSABLE INCOME
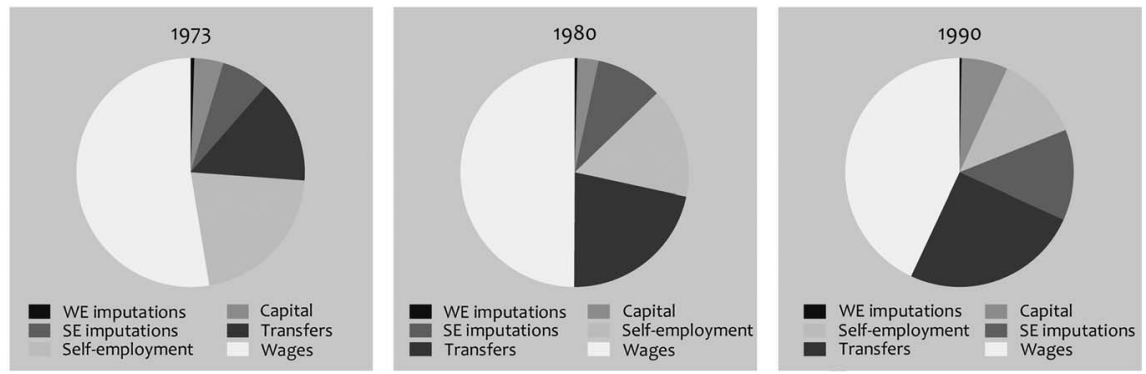

Source: Calculated using sgini module for STATA by Philippe van Kerm.

Entering such a debate in depth is beyond the scope of this paper, but the decomposition of disposable income in Figure 2 can provide an idea of the forces behind inequality change. Apart from wages, self-employment income, capital income and transfers, two kinds of imputed incomes are included. These are non-monetary flows accruing to households, that have been given an approximate value in the survey. "WE imputations» (those related to wage-earning activities) include in-kind compensation and meals at the workplace, while "SE imputations» (related to self-employment) are home consumption and housing services in owner-occupied housing ${ }^{28}$.

Employment incomes were clearly the main components of disposable household resources but their share decreased over time (accounting each year for 53, 50 and 43 per cent, respectively). The items gaining weight were mainly transfers (due to the development of the welfare state: total transfers increased from 14 to 25 per cent) and capital income (from 4 to 7 per cent). Because capital income is concentrated at the top, while public benefits go mainly to the bottom, both changes could have counteracting effects on total

\section{(footnote continued)}

culmination of the pre-oil-shock growth in the country, while 1980 was a period of economic distress, and in 1990 the country was back on the ascending side of the cycle. We cannot draw strong conclusions from them.

28 The imputation of income from owner-occupied housing is conceptually important but empirically complicated. Using only monetary components to measure the standards of living of the households can be highly misleading if renters coexist with owner-occupiers, which is of course the case here (although around 80 per cent of the households fall in the second category). The survey includes this variable, which is an approximation to the rent a household would pay if it rented its house. The calculations are certainly not flawless, and moreover it should only be imputed in the percentage that the house is paid (i.e. 100 per cent if the family totally owns its house, 50 per cent if half of it is still owed to the bank). This adjustment is not possible here because of lack of data. However, I consider it necessary to include this element, especially in a context marked by rising property prices and with the housing bubble on the horizon. 
FIGURE 3

INCOME COMPOSITION BY DECILES

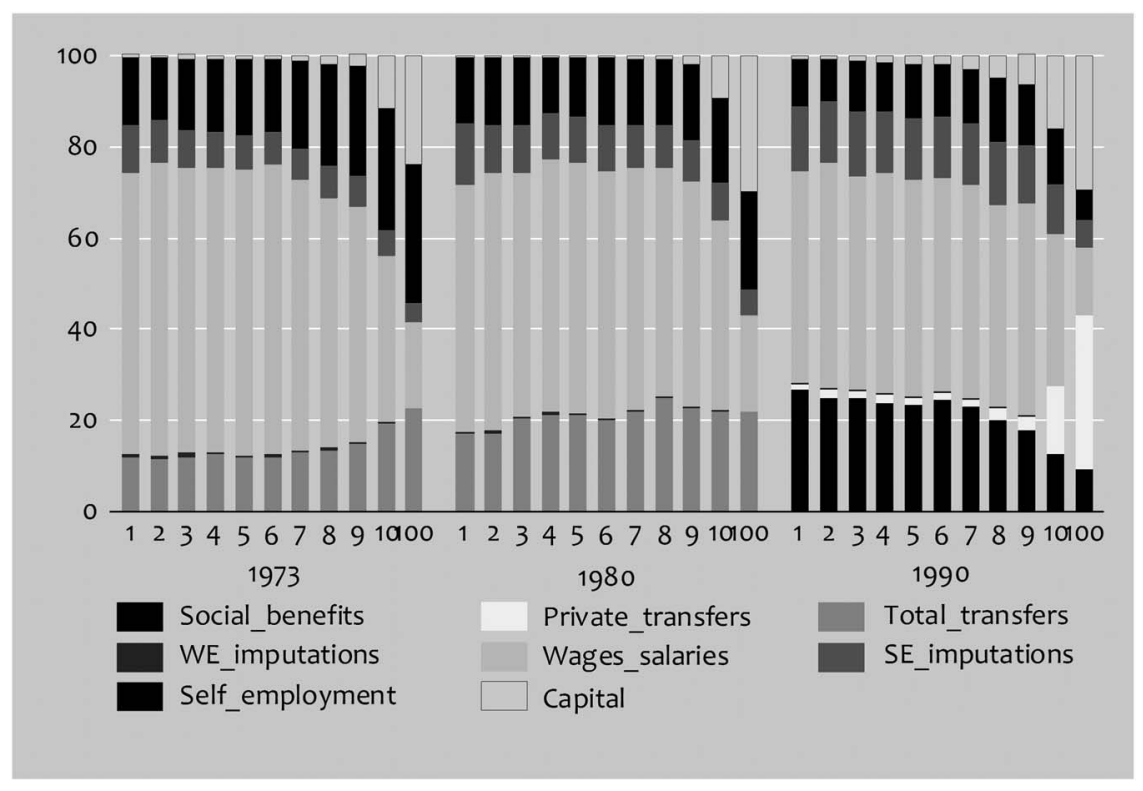

Notes: In all cases incomes are equivalised by household size, using the OECD scale. Source: Calculated using sgini module for STATA by Philippe van Kerm.

inequality. Also self-employment imputations had a growing participation (from 7 to 13 per cent), mainly due to the imputed rentals from owneroccupied housing.

This general composition of disposable income is of course very variable along the social ladder, as can be seen in Figure 3. In the bottom deciles transfers and salary income make up most revenues. Social benefits and private transfers are, regrettably, not disaggregated in the 1973 and 1980 data, but the progressive nature of the former can be seen clearly in 1990 . Wages have maximum participation in the middle deciles and selfemployment income is somewhat skewed to the top in the first years. Revenues from capital are the most concentrated: almost absent in the lower classes, they constitute over 10 per cent of income for the upper decile and around 30 per cent for the top 1 per cent. This pattern is similar in other countries (e.g. Piketty 2003).

Figure 4 plots inequality for each component of income, following the decomposition method originally developed by Lerman and Yitzhaki (1985). It shows that employment incomes became slightly more concentrated over the period: wages and salaries went from 50.6 to 53.2 Gini points, and 
FIGURE 4

\section{GINI INDICES FOR COMPONENTS OF DISPOSABLE INCOME}

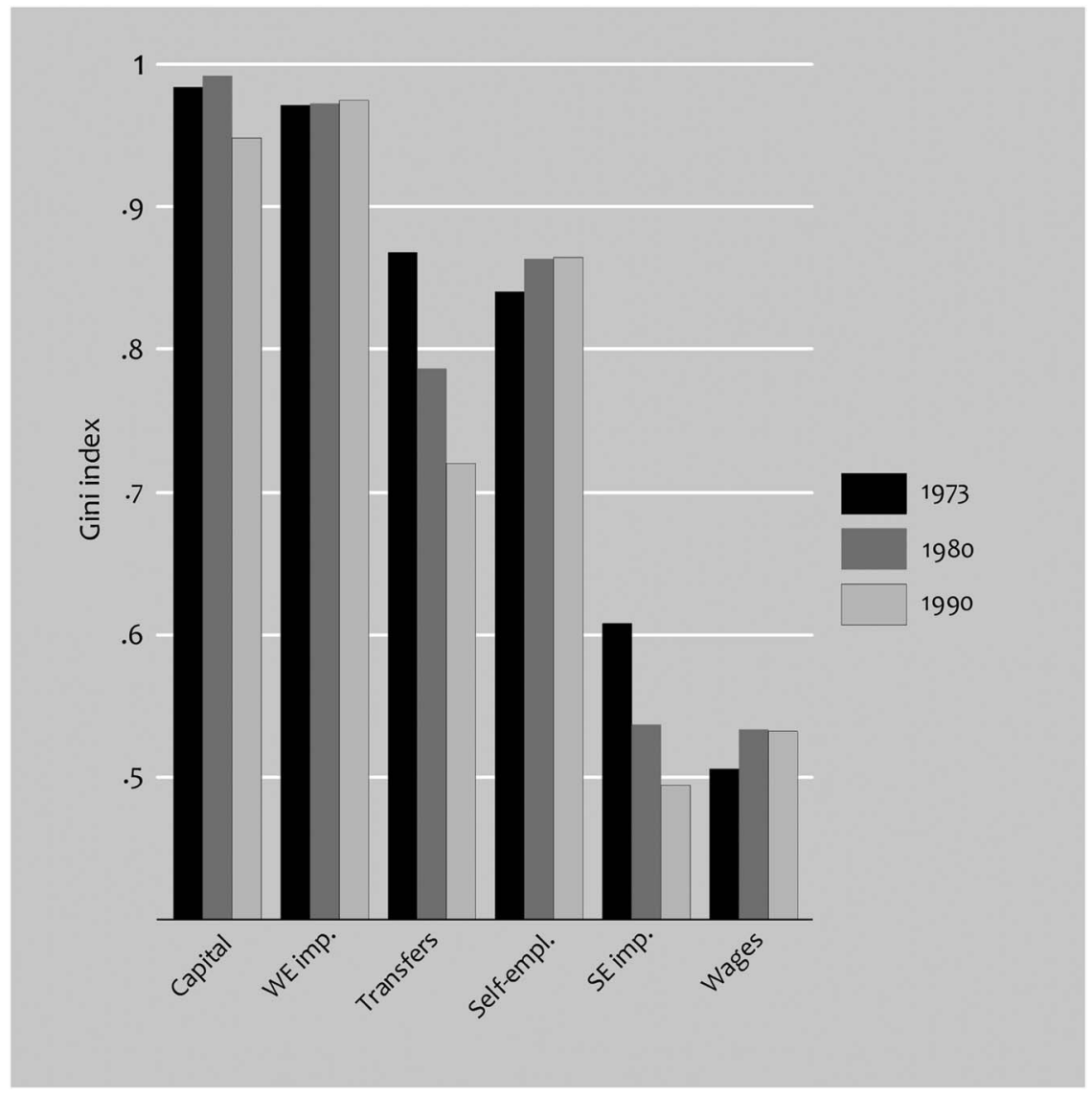

Notes: "In all cases incomes are equivalised by household size, using the OECD scale. «WE imp.» means imputed incomes from labour activity, while «SE imp.» refers to non-monetary self-employment incomes such as that from owneroccupied housing.

Source: Calculated using sgini module for STATA by Philippe van Kerm.

self-employment income from 84.1 to $86.5^{29}$. The element with the most uneven distribution is capital income (99-95 Gini points), the increasing participation of which also pulled up total inequality. These forces were

29 It should be remembered that this is the Gini index for each component over the whole population, not only over the households which do have each kind of income. If we consider only families with salary income, for example, we get a fairly constant Gini index of 34-36. The two computations show different facts (and neither of them is wage inequality among the workforce, which would require working with individual-level data). 
TABLE 12

LEVELS AND GROWTH OF DISPOSABLE EQUIVALENT INCOME

\begin{tabular}{|l|c|c|c|c|c|c|}
\hline & \multicolumn{2}{|c|}{ Mean (constant 1990 ptas) } & \multicolumn{3}{c|}{ Increase } \\
\cline { 2 - 7 } & $\mathbf{1 9 7 3}$ & $\mathbf{1 9 8 0}$ & $\mathbf{1 9 9 0}$ & $\mathbf{1 9 8 0 / 7 3}$ & $\mathbf{1 9 9 0 / 8 0}$ & $\mathbf{1 9 9 0 / 7 3}$ \\
\hline Decile 1 & 257,168 & 279,276 & 359,219 & $8.6 \%$ & $28.6 \%$ & $39.7 \%$ \\
\hline Decile 2 & 385,927 & 440,857 & 540,182 & $14.2 \%$ & $22.5 \%$ & $40.0 \%$ \\
\hline Decile 3 & 475,042 & 543,928 & 652,221 & $14.5 \%$ & $19.9 \%$ & $37.3 \%$ \\
\hline Decile 4 & 558,261 & 633,925 & 754,046 & $13.6 \%$ & $18.9 \%$ & $35.1 \%$ \\
\hline Decile 5 & 640,977 & 727,475 & 863,084 & $13.5 \%$ & $18.6 \%$ & $34.7 \%$ \\
\hline Decile 6 & 737,294 & 826,796 & 974,459 & $12.1 \%$ & $17.9 \%$ & $32.2 \%$ \\
\hline Decile 7 & 854,088 & 950,880 & $1,111,928$ & $11.3 \%$ & $16.9 \%$ & $30.2 \%$ \\
\hline Decile 8 & $1,015,400$ & $1,119,565$ & $1,302,864$ & $10.3 \%$ & $16.4 \%$ & $28.3 \%$ \\
\hline Decile 9 & $1,260,337$ & $1,373,365$ & $1,615,610$ & $9.0 \%$ & $17.6 \%$ & $28.2 \%$ \\
\hline Decile 10 & $2,369,292$ & $2,399,594$ & $3,004,124$ & $1.3 \%$ & $25.2 \%$ & $26.8 \%$ \\
\hline Top 1\% & $5,691,256$ & $5,705,531$ & $8,444,164$ & $0.3 \%$ & $48.0 \%$ & $48.4 \%$ \\
\hline Total & 855,313 & 929,507 & $1,117,712$ & $8.7 \%$ & $20.2 \%$ & $30.7 \%$ \\
\hline Ratio 10/1 & 9.21 & 8.59 & 8.36 & 0.15 & 0.88 & 0.68 \\
\hline Ratio 10/5 & 3.70 & 3.30 & 3.48 & 0.09 & 1.35 & 0.77 \\
\hline Ratio 5/1 & 2.49 & 2.60 & 2.40 & 1.57 & 0.65 & 0.87 \\
\hline
\end{tabular}

Notes: Deciles of individuals based on disposable per capita equivalent income, obtained with the OECD scale.

Sources: Calculated using GDP deflators from Prados de la Escosura (2003).

offset by a more homogeneous distribution of SE imputations and transfers, income sources which, as we have seen, experienced substantial growth over the period.

\subsection{Inequality in Levels}

As we can see, the near stability of the Gini index does not imply the absence of several interesting distributive changes. A further image emerges if we take a look at the levels of income: in order to do so, Table 12 displays mean disposable per capita equivalent income by deciles, in constant 1990 pesetas. It makes it possible to observe that all deciles experienced an 
increase in their purchasing power during the period ${ }^{30}$. The profiles of growth are however dissimilar in the two sub-periods: while during the seventies growth was higher at the lower-mid levels, in the nineties it was the extremes which benefited the most (pointing towards the expansion in welfare state transfers in the case of the low-income households). If we look at the top 1 per cent, we even find stagnation in the first sub-period (the oil crisis decade) and a very significant recovery in the second. The ratios in the last rows confirm the same impression of a weak decrease in economic distances.

Let us recall that the Gini index and other related indicators measure relative inequality (i.e. independent from the scale: constant if all incomes are multiplied by the same factor). If absolute differences in income are also thought to be important, we can calculate an absolute Gini, which is the same index without normalisation to the mean (as put forward by Ravallion 2003). Carrying out this exercise for the 3 years, we obtain an increase in the absolute inequality index of 24 per cent between 1973 and 1990. Relative economic distances did not change that much, but they did in absolute terms, in actual consumption capacity ${ }^{31}$.

\section{CONCLUDING REMARKS}

In this paper I have analysed the sources available for disposable income distribution in Spain during the years surrounding the transition to democracy. The main data come from the Household Budget Surveys conducted by the INE, which contain very rich information but need to be used with caution. It is widely known that they suffer from severe underreporting - and, furthermore, that this is not homogeneous across income sources. Such a problem means that the under-estimation of incomes is not homogeneous across income levels, biasing the inequality indices readily obtained from the data.

I have performed a two-step correction procedure, trying to identify under-reporting first with an Engel's curve approach (contrasting the selfemployed with the wage-earners in their incomes and food/energy expenditure) and then with an aggregate adjustment to the magnitudes of the household sector given in National Accounts. The results allow us to question the conventional wisdom that inequality strongly diminished in Spain during these decades. The Gini indices of all surveys are pulled up by the correction and the trend across the years significantly weakens.

${ }^{30}$ Disposable income is an indicator of consumption capacity of households, but it should be borne in mind that it is still subject to indirect taxes, so changes in consumption taxation also affect final material well-being.

31 The issue is more complicated. If we take into account diminishing utility of incomes, it can be argued that absolute differences in income would be more accurately expressed after some kind of functional transformation to reflect it. 
This leads directly to a further question. Did the transition to democracy not introduce significant distributive improvements? Political economy theory would expect from democracy an inclination to favour the lower classes (at least, relative to a right-wing dictatorship as Spain had recently suffered), via labour market regulation, welfare state benefits, and progressive taxation. We do witness an increase in the importance of transfers received by the households at the bottom of the distribution, reflecting welfare state development in the years after 1977. However, they did not outdo forces pulling in the opposite direction. The tax system did not become progressive, as pointed out by Torregrosa (n.d.). The absolute gains from growth went mostly to the upper classes.

Economic growth and decline in inequality in the years after 1950 have been said to facilitate the transition in the 1970s. Prados de la Escosura (2008) interpreted in this way the elimination of absolute poverty and the growth of the middle class, which would have permitted the stabilisation of democracy, contrary to what happened in the interwar period. This evolution, however, does not seem to have gone much further. Liberalisation brought about new distributive forces, while in the context of general economic distress in Europe, the new political system did not turn out to disproportionately favour the less well-off. At least, it could not effectively counteract market forces towards growing inequality.

This is, of course, a political choice, reflecting the equilibrium between classes or interest groups in the young parliamentary state. In this sense, the lack of economic equalisation could be enlightening about the access to political power. Future work will explore the relationship between inequality and political transitions in a broader comparative context, with special attention to Latin American countries, which could provide valuable insights.

\section{REFERENCES}

Accardo, J., Bellamy, V., Consales, G., Fesseau, M., Laidier, S., and Raymaud, E. (2009): "Inequalities Between Households in the National Accounts - Breakdown of Household Accounts». INSEE Working Paper.

Acemoglu, D., Naidu, S., Restrepo, P., and Robinson, J. A. (2013): «Democracy, Redistribution and Inequality». NBER Working Papers 19746, National Bureau of Economic Research.

Alcaide, A., and Alcaide, J. (1974): «Metodología Para la Estimación de la Distribución Personal de la renta en España en 1970». Hacienda Pública Española 1 (26), pp. 55-63.

Alcaide, J. (2000): «La Renta Nacional de España y su Distribución. Serie años 1898 a 1998», in J. V. Fuertes (ed.), 1900-2000. Historia de un Esfuerzo Colectivo: Cómo España Superó el Pesimismo y la Pobreza. cap. XXII, vol. II Madrid: Fundación BSCH, pp. 375-449.

Alvaredo, F. (2011): "A Note on the Relationship Between Top Income Shares and the Gini Coefficient». Economics Letters 110 (3), pp. 274-277.

Alvaredo, F., and Saez, E. (2009): "Income and Wealth Concentration in Spain from a Historical and Fiscal Perspective». Journal of the European Economic Association 7 (5), pp. 1140-1167. 
Andrés, L., and Mercader-Prats, M. (2001): «Sobre la fiabilidad de los datos de renta en el Panel de Hogares de la Unión Europea (PHOGUE, 1994)». Working Papers wp0102, Department of Applied Economics at Universitat Autònoma of Barcelona.

Argimón, I.; González-PÁramo, J. M., and Salas, R. (1987): «¿Quién Pagaba los Impuestos Indirectos en España? Un Ejercicio de Reparto de la Carga Impositiva Indirecta en 1980». Hacienda Pública Española, 104, pp. 99-127.

Atkinson, A. (2000): «The Changing Distribution of Income: Evidence and Explanations». German Economic Review 1, pp. 3-18.

Atkinson, A. (2007): "Measuring Top Incomes: Methodological Issues», in A. Atkinson, and T. Piketty (eds), Top Incomes over the 20th Century: A Contrast Between Continental European and English-Speaking Countries. Oxford: Oxford University Press, pp. 18-42.

Attanasio, O. P. (1999): "Consumption", in J. B. Taylor, and M. Woodford (eds), Handbook of Macroeconomics. Volume 1 of Handbook of Macroeconomics, Chapter 11, Amsterdam: Elsevier, pp. 741-812.

Ayala, L.; Jurado, A., and Pedraja, F. (2006): «Desigualdad y Bienestar en la Distribución Intraterritorial de la Renta, 1973-2000». Investigaciones Regionales 8, pp. 5-30.

Ayala, L.; Martínez, R., and Ruiz-Huerta, J. (1996): La Distribución de la renta en España desde una Perspectiva Internacional: Tendencias y Factores de Cambio. Volume VI, La desigualdad de recursos Madrid: Fundación Argentaria, pp. 315-440.

Barreix, A.; BÈs, M., and Roca, J. (eds) (2009): La Equidad Fiscal en Centroamérica, Panamá y República Dominicana. Washington: BID-Eurosocial.

Bosch-Domenech, A. (1991): «Economies of Scale, Location, Age, and Sex Discrimination in Household Demand». European Economic Review 35 (8), pp. 1589-1595.

Budd, E., and Radner, D. (1975): "The Bureau of Economic Analysis and Current Population Survey Size Distributions: Some Comparisons for 1964», in J. D. Smith (ed.), The Personal Distribution of Income and Wealth. Volume 39 of Studies in Income and Wealth. New York: Columbia University Press, pp. 449-558.

Buhmann, B., et al. (1988): «Equivalence Scales, Well-Being, Inequality, and Poverty: Sensitivity Estimates across Ten Countries Using the Luxembourg Income Study (LIS) Database». Review of Income and Wealth 34 (2), pp. 115-142.

Canberra Expert Group (2011): Handbook on Household Income Statistics, 2nd edn. Geneva: United Nations Economic Commission for Europe.

Cowell, F. A.; Litchfield, J., and Mercader-Prats, M. (1999): «Income Inequality Comparisons with Dirty Data: The UK and Spain during the 1980s». STICERD Distributional Analysis Research Programme Papers 45, Suntory and Toyota International Centres for Economics and Related Disciplines, LSE.

CutAndA, A. (2003): «An Empirical Investigation of the Effect of Borrowing Constraints on Spanish Consumption». Spanish Economic Review 5, pp. 63-84.

Del Río, C., and Ruiz-Castillo, J. (1996): Ordenaciones de Bienestar e Inferencia Estadística. El caso de las EPF de 1980-81 y 1990-91. Volume 6. Madrid: Fundación Argentaria.

Díaz, C., and Fernández, R. (1993): «El Fraude en las rentas del trabajo: Salarios y Pensiones». Cuadernos de Actualidad 7, pp. 268-274.

Duclos, J. Y., and Mercader-Prats, M. (1999): «Household Needs and Poverty: With Application to Spain and the U.K». Review of Income and Wealth 45 (1), pp. 77-98.

EASTERLY, W. R. (2004): "Globalization, Inequality, and Development: The Big Picture». Monetary and Economic Studies 22 (S1), pp. 57-87.

ECLAC. (1991): "Magnitud de la pobreza en América Latina en los años ochenta». Number 81 in Estudios e informes de la CEPAL. Santiago de Chile. 
Engel, E.; Galetovic, A., and Raddatz, C. (1999): "Taxes and Income Distribution in Chile: Some Unpleasant Redistributive Arithmetic». Journal of Development Economics 59 (1), pp. 155-192.

Engström, P., and Holmlund, B. (2009): «Tax Evasion and Self-Employment in a HighTax Country: Evidence from Sweden». Applied Economics 41 (19), pp. 2419-2430.

Estruch, A. (1996): Los Efectos Redistributivos del gasto Social de las Administraciones Centrales y Autonómicas. Volume VII, Sector Público y Redistribución Madrid: Fundación Argentaria, pp. 261-290.

FixleR, D., and Johnson, D. (2012): «Accounting for the Distribution of Income in the U.S. National Accounts». Paper prepared for the NBER Conference on Research in Income and Wealth "Measuring Economic Stability and Progress Conference», (September 30). Cambridge, Massachusetts.

Garde, J. A.; Martínez, R., and Ruiz-Huerta, J. (1996): Los Estudios Sobre Distribución de la renta en España: Fuentes, Resultados y Perspectivas de Futuro. Volume VI. Madrid: Fundación Argentaria, pp. 257-314.

Goerlich, F. J., and Mas, M. (2001): «Inequality in Spain 1973-91: Contribution to a Regional Database». Review of Income and Wealth 47 (3), pp. 361-378.

Gradín, C. (2002): «Polarization and Inequality in Spain: 1973-1991». Journal of Income Distribution 11 (1-2), pp. 34-52.

Gradín, C.; Cantó, O., and Del Río, C. (2008): «Inequality, Poverty and Mobility: Choosing Income or Consumption as Welfare Indicators». Investigaciones Economicas 32 (2), pp. 169-200.

Hurst, E.; Li, G., and Pugsley, B. (2014): «Are Household Surveys Like Tax Forms? Evidence from Income Underreporting of the Self Employed». The Review of Economics and Statistics 96 (1), pp. 19-33.

Instituto Nacional de Estadística (1977): La Renta Nacional y su Distribución 1976. Madrid: INE.

Johansson, E. (2005): "An Estimate of Self-Employment Income Underreporting in Finland». Nordic Journal of Political Economy 31 (1), pp. 99-109.

Krugman, P. R. (2000): «Technology, Trade and Factor Prices». Journal of International Economics 50 (1), pp. 51-71.

KuzNETS, S. (1955): «Economic Growth and Income Inequality». The American Economic Review 45 (1), pp. 1-28.

Labeaga, J.; Preston, I., and Sanchís-Llopis, J. (2004): «Demanda y Escalas de Equivalencia: Evidencia Para España». Cuadernos Económicos del ICE 68, pp. 63-87.

Lerman, R. I., and YitZHAKI, S. (1985): «Income Inequality Effects by Income Source: A New Approach and Applications to the United States». The Review of Economics and Statistics 67 (1), pp. 151-156.

Levy, F., and Temin, P. (2007): «Inequality and Institutions in 20th Century America». NBER Working Papers 13106, National Bureau of Economic Research.

Lyssiotou, P.; Pashardes, P., and Stengos, T. (2004): «Estimates of the Black Economy Based on Consumer Demand Approaches». Economic Journal 114 (497), pp. 622-640.

Marchante Mera, A.; Ortega Aguaza, B.; Soria Torres, T., and Colomer Real, L. (2002): «Renta, Consumo y Ahorro de los Mayores: Un Análisis Aplicado». Estudios de Economía Aplicada 20 (1), pp. 197-215.

Martín-Guzmán, P., et al. (1996): Encuesta de Presupuestos Familiares. Desigualdad y Pobreza en España. Estudio Basado en las Encuestas de Presupuestos Familiares de 1973-74, 1980-81 y 1990-91. Madrid: Instituto Nacional de Estadística and Universidad Autónoma de Madrid. 
Martínez-López, D. (2012): «The Underreporting of Income by Self-Employed Workers in Spain». SERIES 4 (4), pp. 353-371.

McColl, B.; Billing, J.; Kindermann, B., and Burgess, H. (2010): «Micro and Macro Economic Estimates for Australian Households: Recent Developments and Future Directions». Paper presented at the IARIW Annual Meetings, (August 2010). St-Gallen, Switzerland.

Meltzer, A., and Richard, S. (1981): "A Rational Theory of the Size of Government». Journal of Political Economy 89 (5), pp. 914-927.

Mistiaen, J., and Ravallion, M. (2003): "Survey Compliance and the Distribution of Income». Policy Research Working Paper 2956, World Bank, Washington, DC.

Morelli, S.; Smeeding, T., and Thompson, J. (2015): «Post-1970 Trends in Within-Country Inequality and Poverty: Rich and Middle Income Countries», in A. Atkinson, and F. Bourguignon (eds), Handbook of Income Distribution. Volume 2A, Amsterdam: Elsevier B.V., pp. 596-693.

Neri, A., and ZizzA, R. (2010): "Income Reporting Behaviour in the SHIW». Temi di Discussione 777, Bank of Italy.

Oliver, J. (1997): "Ingreso, Consumo y Ahorro de las Familias: Propuesta de una Metodología Para la Explotación de la Encuesta de Presupuestos Familiares». Documentos de Trabajo FIES, (1), 132.

Oliver, J.; Ramos, X., and Raymond-BarÀ, J. (2001): «Anatomía de la Distribución de la renta en España, 1985-1996: la Continuidad de la Mejora». Papeles de Economía Española 88, pp. 67-88.

Pena Trapero, J. B. (dir) (1996): Distribución Personal de la renta en España: Corrección y Modelización de la Información Básica: Desigualdad y Análisis. Madrid: Pirámide.

Pijoan-Mas, J., and Sánchez-Marcos, V. (2010): "Spain is Different: Falling Trends of Inequality». Review of Economic Dynamics 13, pp. 154-178.

PiketTy, T. (2003): «Income Inequality in France, 1901-1998». Journal of Political Economy 111 (5), pp. 1004-1042.

Pissarides, C. A., and Weber, G. (1989): «An Expenditure-Based Estimate of Britain's Black Economy». Journal of Public Economics 39 (1), pp. 17-32.

Pou, L., and Alegre, J. (2002): «La Encuesta Continua de Presupuestos Familiares: Descripción, Representatividad y Propuestas de Metodología para la Explotación de la Información de los Ingresos y el Gasto». Documento de Trabajo 172/2002, Fundación de las Cajas de Ahorro Confederadas.

Prados De La Escosura, L. (2003): El Progreso Económico de España (1850-2000). Bilbao: Fundación BBVA.

Prados De La Escosura, L. (2008): «Inequality, Poverty and the Kuznets Curve in Spain, 1850-2000». European Review of Economic History 12 (3), pp. 287-324.

Pérez-Duarte, S.; SÁnchez-Muñoz, C., and Törmälehto, V. (2010): «Re-Weighting to Reduce Unit Non-Response Bias in Household Wealth Surveys: A Cross-Country Comparative Perspective Illustrated by a Case Study». European Conference on Quality in Official Statistics, Helsinki.

Ravallion, M. (2003): «The Debate on Globalization, Poverty and Inequality: Why Measurement Matters». International Affairs 79 (4), pp. 739-754.

SANZ, B. (1995): «La Articulación micro-macro en el Sector Hogares: de la Encuesta de Presupuestos Familiares a la Contabilidad Nacional». Papeles de trabajo, Instituto de Estudios Fiscales 1995/27.

Sen, A. (1992): Inequality Reexamined. Oxford: Clarendon Press.

TEDDS, L. (2010): «Estimating the Income Reporting Function for the Self-Employed». Empirical Economics 38 (3), pp. 669-687. 
Torregrosa-Hetland, S. (n.d.): «Did Democracy bring Redistribution? Insights from the Spanish Tax System (1960-1990)». European Review of Economic History, doi:10.1093/ereh/hev006, forthcoming.

\section{APPENDICES TO «STICKY INCOME INEQUALITY IN THE SPANISH TRANSITION (1973-1990)»}

Sara Torregrosa Hetland

\section{A. HOUSEHOLDS AND BUDGET CONSTRAINT BY DECILES}

Table A1 depicts the distribution of households according to the relation between their incomes and expenditures, extending the data shown in the main text by breaking down deciles of income. We already knew that the number of households spending more than they claimed to earn was decreasing as we moved to more recent surveys. Here, we can also see significant differences across the (reported) income distribution in each sample.

In all three surveys, the percentage of households spending less than or equal to their yearly income is increasing with income. This, of course, is not surprising since part of the explanation lies in the real behaviour of households with different economic means. In almost all deciles, however, the majority of households lie within the 1-2 interval.

Casual observation of this table leads to the conclusion that adjusting incomes to expenditures will bring up the revenues of the poor more than those of the rich (in percentage terms), leading to lower levels of inequality. To the extent that some households do spend more than their yearly income in a given year, and that households with positive savings are also underreporting their earnings, such an adjustment can only be a small part of the solution and could even introduce additional biases.

\section{B. EFFECTS OF ADJUSTING SELF-EMPLOYMENT EARNINGS EXCLUSIVELY}

In this paper, the estimation of under-reporting of the self-employed à la Pissarides-Weber is part of a wider strategy, to obtain adjustment of all incomes to National Accounts. We can, however, ask ourselves what would be the result in terms of inequality of up-scaling earnings after this first under-reporting inquiry. This is shown in Table B1.

The exercise has only a limited effect on the Gini indices, which are slightly increased (compare with the original data in the first columns of Table 5). This is because I apply here coefficients of $1.21,1.26$ and 1.17 (as resulting from Table 6 , and significantly smaller than those applied in the adjustment to NA exercise, Table 8), and only to self-employment incomes, which are a limited part of the total (always under 25\%). 
TABLE A1

DISTRIBUTION ACCORDING TO THE RATIO (EXPENDITURE + NET SAVINGS)/ INCOME

\begin{tabular}{|c|c|c|c|c|c|c|}
\hline & & $0-1(\%)$ & $1-2(\%)$ & $2-4(\%)$ & $>4(\%)$ & Total $(\%)$ \\
\hline \multirow[t]{10}{*}{1973} & Decile 1 & 28 & 52 & 16 & 5 & 100 \\
\hline & Decile 2 & 28 & 54 & 16 & 2 & 100 \\
\hline & Decile 3 & 29 & 56 & 14 & 1 & 100 \\
\hline & Decile 4 & 26 & 59 & 14 & 1 & 100 \\
\hline & Decile 5 & 28 & 60 & 12 & 1 & 100 \\
\hline & Decile 6 & 28 & 61 & 10 & 0 & 100 \\
\hline & Decile 7 & 31 & 60 & 8 & 0 & 100 \\
\hline & Decile 8 & 34 & 59 & 7 & 0 & 100 \\
\hline & Decile 9 & 36 & 57 & 7 & 0 & 100 \\
\hline & Decile 10 & 41 & 55 & 4 & 0 & 100 \\
\hline \multirow{10}{*}{1980} & Decile 1 & 36 & 46 & 15 & 4 & 100 \\
\hline & Decile 2 & 34 & 52 & 12 & 1 & 100 \\
\hline & Decile 3 & 35 & 53 & 11 & 1 & 100 \\
\hline & Decile 4 & 33 & 57 & 9 & 1 & 100 \\
\hline & Decile 5 & 34 & 56 & 9 & 0 & 100 \\
\hline & Decile 6 & 35 & 57 & 7 & 0 & 100 \\
\hline & Decile 7 & 35 & 58 & 7 & 0 & 100 \\
\hline & Decile 8 & 39 & 55 & 5 & 0 & 100 \\
\hline & Decile 9 & 43 & 52 & 5 & 0 & 100 \\
\hline & Decile 10 & 50 & 47 & 3 & 0 & 100 \\
\hline \multirow[t]{10}{*}{1990} & Decile 1 & 38 & 41 & 16 & 5 & 100 \\
\hline & Decile 2 & 33 & 50 & 15 & 1 & 100 \\
\hline & Decile 3 & 36 & 51 & 12 & 0 & 100 \\
\hline & Decile 4 & 34 & 55 & 11 & 1 & 100 \\
\hline & Decile 5 & 37 & 55 & 8 & 0 & 100 \\
\hline & Decile 6 & 38 & 54 & 7 & 0 & 100 \\
\hline & Decile 7 & 42 & 52 & 6 & 0 & 100 \\
\hline & Decile 8 & 49 & 46 & 4 & 0 & 100 \\
\hline & Decile 9 & 52 & 45 & 3 & 0 & 100 \\
\hline & Decile 10 & 64 & 34 & 2 & 0 & 100 \\
\hline
\end{tabular}

Note: Households in the first column spend within their budget constraint. A ratio of 2, for example, means that the family reported spending twice as much as its yearly income.

Source: Author's calculations based on Household Budget Surveys. 
TABLE B1

EFFECT OF CORRECTING ONLY THE UNDER-REPORTING OF THE SELFEMPLOYED

\begin{tabular}{|l|c|c|c|}
\hline & $\mathbf{1 9 7 3}$ & $\mathbf{1 9 8 0}$ & $\mathbf{1 9 9 0}$ \\
\hline Total (Hh) & 36.78 & 34.43 & 33.25 \\
OECD & 33.13 & 32.03 & 30.11 \\
OECD_mod & 32.57 & 31.36 & 29.49 \\
\hline
\end{tabular}

Source: Author's calculations.

\section{DATA AGGREGATES COMPARISON}

The following tables show the data involved in each calculation of scalingup factors, following the scheme in Table 7 of the text. Note that $m$ corresponds to the net definition (leaving imputations aside). The value for NOS is not applied in the up-scaling procedure (the results from PissaridesWeber equation are used instead), as is explained in the text, because adjustment to the National Accounting framework in this flow should not be complete.

\section{ROBUSTNESS: OTHER EQUIVALENCE SCALES AND INDICES}

Only the preferred estimates are shown in the text, which use the Gini index and the OECD equivalence scale. Other indicators have been calculated, leading to similar results: higher inequality in up-scaled data, slight and erratic decrease over time.

\section{E. ROBUSTNESS: ALTERNATIVE ADJUSTMENTS OF TRANSFERS}

The up-scaling of transfers undertaken in the main estimation attempts to distinguish between private flows and public benefits. Both have been found to have significantly different reporting behaviour in the 1990 survey, which is the only one of the three where they are explicitly differentiated in the data. An approximation has been made in the previous years to the distinct profiles of compliance, based on those results. However, the procedure might introduce a significant level of uncertainty.

In order to look more closely at the problem, I have performed two alternative calculations (see Table E1). The first does not correct transfer incomes at all, and thus leaves the original data for this component untouched, combining it with the other up-scaled incomes to obtain the total. The second procedure applies a uniform correction to all transfer income in all deciles (even for 1990, in order to establish the bias). 
TABLE C1

HBS AND NA HOUSEHOLD INCOME AGGREGATES, 1973

\begin{tabular}{|c|c|c|c|c|c|c|c|c|c|c|}
\hline \multirow[b]{2}{*}{$\begin{array}{l}\text { Self-employment } \\
\text { income }\end{array}$} & \multicolumn{2}{|c|}{ HBS (net) } & \multicolumn{2}{|c|}{ Direct taxes } & \multirow{2}{*}{$\begin{array}{c}\begin{array}{c}\text { HBS } \\
\text { grossed }\end{array} \\
\\
\\
648,148\end{array}$} & \multicolumn{2}{|c|}{ NA (gross) } & \multirow{2}{*}{$\begin{array}{c}\begin{array}{c}\text { Gross ratio } \\
(\%)\end{array} \\
\\
\\
59.9\end{array}$} & \multirow{2}{*}{$\begin{array}{c}\begin{array}{c}\text { Net ratio } \\
(\%)\end{array} \\
\\
\\
58.6\end{array}$} & \multirow{2}{*}{$\begin{array}{c}\boldsymbol{m} \\
\\
2.07\end{array}$} \\
\hline & $\begin{array}{c}\text { Monetary } \\
\text { Imputations } \\
\text { Rentals } \\
\text { Total }\end{array}$ & $\begin{array}{r}397,269 \\
210,105 \\
6,140 \\
613,514\end{array}$ & Total & 34,634 & & $\begin{array}{l}\text { GOS } \\
\text { FKC } \\
\text { NOS }\end{array}$ & $\begin{array}{r}1,173,484 \\
91,708 \\
1,081,776\end{array}$ & & & \\
\hline Labour income & $\begin{array}{c}\text { Monetary } \\
\text { Imputations } \\
\text { Total }\end{array}$ & $\begin{array}{r}1,184,062 \\
15,467 \\
1,199,529\end{array}$ & Total & 419,511 & $1,619,040$ & WC & $2,029,553$ & 79.8 & 74.5 & 1.35 \\
\hline Capital income & Total (mon) & 29,305 & Total & 11,442 & 40,746 & Total & 139,001 & 29.3 & 23.0 & 4.35 \\
\hline Transfer income & Total & 187,310 & Total & 2,347 & 189,657 & Total & 472,215 & 40.2 & 39.7 & 2.51 \\
\hline $\begin{array}{l}\text { Disposable } \\
\text { income }\end{array}$ & Total & $2,029,658$ & & la & $2,029,658$ & Total & $3,099,302$ & 65.5 & 65.5 & 1.53 \\
\hline
\end{tabular}

$m$ : Scaling-up factor obtained (for net incomes); GOS: Gross Operating Surplus; FKC: Fixed Capital Consumption; NOS: Net Operating Surplus; WC: Wage Compensation; na: non-applicable.

Sources: Author's calculations with 1973 HBS and NA (Instituto Nacional de Estadística, 1983) and Pena Trapero (1996). Figures from National Accounts always refer exclusively to the household sector. 
TABLE C2

HBS AND NA HOUSEHOLD INCOME AGGREGATES, 1980

\begin{tabular}{|c|c|c|c|c|c|c|c|c|c|c|}
\hline \multirow[b]{2}{*}{$\begin{array}{l}\text { Self-employment } \\
\text { income }\end{array}$} & \multicolumn{2}{|c|}{ HBS (net) } & \multicolumn{2}{|c|}{ Direct taxes } & \multirow{2}{*}{$\begin{array}{c}\begin{array}{c}\text { HBS } \\
\text { grossed }\end{array} \\
2,310,413\end{array}$} & \multicolumn{2}{|c|}{ NA (gross) } & \multirow{2}{*}{$\begin{array}{c}\text { Gross } \\
\text { ratio }(\%) \\
\\
65.0\end{array}$} & \multirow{2}{*}{$\begin{array}{c}\begin{array}{c}\text { Net } \\
\text { ratio (\%) }\end{array} \\
\\
62.4\end{array}$} & \multirow[b]{2}{*}{$\begin{array}{c}\boldsymbol{m} \\
2.15\end{array}$} \\
\hline & $\begin{array}{c}\text { Monetary } \\
\text { Imputations } \\
\text { Rentals } \\
\text { Total }\end{array}$ & $\begin{array}{r}1,062,966 \\
983,735 \\
22,602 \\
2,069,303\end{array}$ & Total & 241,109 & & $\begin{array}{l}\text { GOS } \\
\text { FKC } \\
\text { NOS }\end{array}$ & $\begin{array}{r}3,907,172 \\
350,206 \\
3,556,966\end{array}$ & & & \\
\hline Labour income & $\begin{array}{c}\text { Monetary } \\
\text { Imputations } \\
\text { Total }\end{array}$ & $\begin{array}{r}4,317,943 \\
43,771 \\
4,361,714\end{array}$ & Total & $2,594,067$ & $6,955,781$ & WC & $7,797,509$ & 89.2 & 83.8 & 1.19 \\
\hline Capital income & Total (mon) & 89,079 & Total & 69,440 & 158,518 & Total & 372,411 & 42.6 & 29.4 & 3.40 \\
\hline Transfer income & Total & $1,149,301$ & Total & 87,127 & $1,236,428$ & Total & $2,442,233$ & 50.6 & 47.1 & 2.05 \\
\hline $\begin{array}{l}\text { Disposable } \\
\text { income }\end{array}$ & Total & $7,669,397$ & & na & $7,669,397$ & Total & $11,049,326$ & 69.4 & 69.4 & 1.44 \\
\hline
\end{tabular}

m: Scaling-up factor obtained (for net incomes); GOS: Gross Operating Surplus; FKC: Fixed Capital Consumption; NOS: Net Operating Surplus; WC: Wage Compensation; na: non-applicable.

Source: Author's calculations with 1980 HBS and NA (Instituto Nacional de Estadística, 2014) and Pena Trapero (1996). Figures from National Accounts always refer exclusively to the household sector. 
TABLE C3

HBS AND NA HOUSEHOLD INCOME AGGREGATES, 1990

\begin{tabular}{|c|c|c|c|c|c|c|c|c|c|c|}
\hline \multirow[b]{2}{*}{$\begin{array}{l}\text { Self- } \\
\text { employment } \\
\text { income }\end{array}$} & \multicolumn{2}{|c|}{ HBS (net) } & \multicolumn{2}{|c|}{ Direct taxes } & \multirow{2}{*}{$\begin{array}{c}\begin{array}{c}\text { HBS } \\
\text { grossed }\end{array} \\
\\
8,360,516\end{array}$} & \multicolumn{2}{|c|}{ NA (gross) } & \multirow{2}{*}{$\begin{array}{c}\begin{array}{c}\text { Gross } \\
\text { ratio }(\%)\end{array} \\
72.1\end{array}$} & \multirow{2}{*}{$\begin{array}{c}\begin{array}{c}\text { Net } \\
\text { ratio } \\
(\%)\end{array} \\
\\
69.2\end{array}$} & \multirow[b]{2}{*}{$\begin{array}{c}\boldsymbol{m} \\
\\
\\
\\
\\
\end{array}$} \\
\hline & $\begin{array}{c}\text { Monetary } \\
\text { Imputations } \\
\text { Rentals } \\
\text { Total }\end{array}$ & $\begin{array}{r}2,954,395 \\
4,229,056 \\
104,158 \\
7,287,608\end{array}$ & Total & $1,072,907$ & & $\begin{array}{l}\text { GOS } \\
\text { FKC } \\
\text { NOS }\end{array}$ & $\begin{array}{r}13,206,456 \\
1,606,303 \\
11,600,153\end{array}$ & & & \\
\hline Labour income & $\begin{array}{c}\text { Monetary } \\
\text { Imputations } \\
\text { Total }\end{array}$ & $\begin{array}{r}12,280,468 \\
102,544 \\
12,383,012\end{array}$ & Total & $9,209,310$ & $21,592,321$ & WC & $23,108,029$ & 93.4 & 89.1 & 1.12 \\
\hline Capital income & Total (mon) & 141,557 & Total & 756,572 & 898,130 & Total & $1,725,920$ & 52.0 & 14.6 & 6.85 \\
\hline $\begin{array}{l}\text { Transfer } \\
\text { income }\end{array}$ & $\begin{array}{c}\text { Public } \\
\text { Private } \\
\text { Total }\end{array}$ & $\begin{array}{r}4,797,545 \\
439,019 \\
5,236,563\end{array}$ & Total & 310,962 & $5,547,525$ & $\begin{array}{l}\text { Public } \\
\text { Private } \\
\text { Total }\end{array}$ & $\begin{array}{l}7,177,969 \\
1,766,759 \\
8,944,728\end{array}$ & $\begin{array}{l}71.2 \\
24.8 \\
62.0\end{array}$ & $\begin{array}{l}69.9 \\
24.8 \\
58.5\end{array}$ & $\begin{array}{l}1.43 \\
4.02 \\
1.65\end{array}$ \\
\hline $\begin{array}{c}\text { Disposable } \\
\text { income }\end{array}$ & Total & $25,048,741$ & & na & $25,048,741$ & Total & $32,908,556$ & 76.1 & 76.1 & 1.31 \\
\hline
\end{tabular}

$m$ : Scaling-up factor obtained (for net incomes); GOS: Gross Operating Surplus; FKC: Fixed Capital Consumption; NOS: Net Operating Surplus; WC: Wage Compensation; na: non-applicable.

Sources: Author's calculations with 1990 HBS and NA (Instituto Nacional de Estadística, 2014), Sanz (1995) and Oliver (1997). Figures from National Accounts always refer exclusively to the household sector. 
TABLE D1

INCOME INEQUALITY ACCORDING TO OTHER EQUIVALENCE SCALES AND INDICES

\begin{tabular}{|c|c|c|c|c|c|c|}
\hline & \multicolumn{2}{|c|}{1973} & \multicolumn{2}{|c|}{1980} & \multicolumn{2}{|c|}{1990} \\
\hline & Original & Corrected & Original & Corrected & Original & Corrected \\
\hline \multicolumn{7}{|c|}{ Gini } \\
\hline Total (Hh) & 36.19 & 36.83 & 34.26 & 33.51 & 33.02 & 34.84 \\
\hline OECD & 32.56 & 34.59 & 31.99 & 32.60 & 29.99 & 32.95 \\
\hline OECD_mod & 31.97 & 33.79 & 31.27 & 31.59 & 29.35 & 32.13 \\
\hline Sqroot & 32.12 & 33.88 & 30.96 & 31.39 & 29.37 & 32.04 \\
\hline \multicolumn{7}{|c|}{ Top $10 \%$ share } \\
\hline Total (Hh) & 26.74 & 28.23 & 25.35 & 25.80 & 24.70 & 27.13 \\
\hline OECD & 25.72 & 27.69 & 25.09 & 25.80 & 23.97 & 26.87 \\
\hline OECD_mod & 25.32 & 27.19 & 24.61 & 25.19 & 23.54 & 26.35 \\
\hline Sqroot & 25.22 & 27.05 & 24.22 & 24.88 & 23.31 & 26.09 \\
\hline \multicolumn{7}{|c|}{ Top 1\% share } \\
\hline Total (Hh) & 5.58 & 6.47 & 5.20 & 6.03 & 4.85 & 7.15 \\
\hline OECD & 5.44 & 6.65 & 5.20 & 6.14 & 4.80 & 7.30 \\
\hline OECD_mod & 5.40 & 6.44 & 5.06 & 5.92 & 4.65 & 7.23 \\
\hline Sqroot & 5.33 & 6.27 & 4.90 & 5.81 & 4.52 & 7.08 \\
\hline \multicolumn{7}{|c|}{ GE (2) index } \\
\hline Total (Hh) & 32.90 & 40.59 & 31.67 & 55.31 & 27.80 & 69.63 \\
\hline OECD & 28.49 & 40.32 & 31.85 & 57.93 & 26.48 & 71.91 \\
\hline \multicolumn{7}{|c|}{ p90/p10 } \\
\hline Total (Hh) & 5.72 & 5.25 & 5.27 & 4.43 & 4.95 & 4.73 \\
\hline OECD & 4.19 & 4.38 & 4.17 & 4.13 & 3.77 & 3.93 \\
\hline \multicolumn{7}{|c|}{ p90/p50 } \\
\hline Total (Hh) & 2.15 & 2.24 & 2.08 & 2.06 & 2.07 & 2.10 \\
\hline OECD & 2.04 & 2.13 & 2.03 & 2.02 & 1.96 & 2.02 \\
\hline
\end{tabular}

Notes: In all indices, the first row represents distribution between households, while the other depicts distribution between individuals according to different equivalence scales. The OECD original and modified scales apply weights 0.7-0.5 and 0.4-0.3 respectively to subsequent adults and minors in the household (under 14). The "Sqroot" scale uses the square root of the household size.

All calculations refer to disposable income. Gross incomes are expected to be more unequally distributed under a progressive direct tax system (which applies especially to 1990).

Source: Author's calculations.

As can be seen, generally the preferred calculation (Table 10) depicts intermediate levels of inequality with respect to the other alternatives presented here (no up-scaling generating higher levels, and uniform up-scaling 
TABLE E1

GINI INDICES UNDER ALTERNATIVE ADJUSTMENTS OF TRANSFER INCOME

\begin{tabular}{|c|c|c|c|}
\hline & 1973 & 1980 & 1990 \\
\hline \multicolumn{4}{|c|}{ No up-scaling of transfer income } \\
\hline Total (Hh) & 38.80 & 36.43 & 35.65 \\
\hline OECD & 35.05 & 33.77 & 32.61 \\
\hline OECD_mod & 34.46 & 33.14 & 32.01 \\
\hline \multicolumn{4}{|c|}{ Uniform up-scaling of transfer income } \\
\hline Total (Hh) & 36.21 & 32.72 & 32.14 \\
\hline OECD & 34.16 & 32.13 & 31.64 \\
\hline OECD_mod & 33.33 & 31.07 & 30.51 \\
\hline
\end{tabular}

Source: Author's calculations.

resulting in lower levels). The exception is equivalent incomes in 1990, where our more precise estimate yields higher inequality than these ones. This could suggest that our approximation under-estimates the effect of this distinct behaviour of private transfers and public benefits, thus leading to inequality still being downward biased in the results. The implication, however, is dependant on the distribution of both components being homogeneous across the years, something unlikely given the development of the welfare state at the time.

\section{F. COMPARING WITH OTHER APPROACHES TO SPANISH INEQUALITY}

The results in this paper differ from those previously obtained using the survey data, because I estimate a higher level of inequality and a smaller decrease over time. This includes the studies reviewed in section 2, based on the HBSs, and also those which have used a different source, the Encuesta Continua de Presupuestos Familiares. This is a rotating household panel also provided by the INE, with quarterly data and households staying in the sample for a maximum of 2 years.

The ECPF consistently displays lower levels of inequality than the HBSs (EPFs). One reason for this might be that it suffers from a larger downward bias, because of sample size and the definition of income employed (notably excluding certain capital incomes). According to some reputable sources, this results in its low reliability for the study of inequality (Eurostat 1999; Goerlich and Mas 2001). Its higher discrepancy with respect to National Accounts can be seen in Pou and Alegre (2002). 
For this reason, differences between my results and those of analyses based on the ECPF are to some extent not surprising. Both Oliver et al. (2001) and Pijoan-Mas and Sánchez-Marcos (2010), for example, provide an account of falling inequality between 1985 and 1996/2000, partially overlapping with the period analysed here ${ }^{32}$. The differing trends, however, are not completely irreconcilable: in fact, a decrease in inequality in the second half of the 1980s could be compatible with general stability when the whole decade is considered (especially knowing that a whole cycle of recession and growth took place during the eighties, and rates of unemployment were similar at the beginning and the end of the decade, around 15\%). Falling inequality in labour market revenues of household heads is also found for the entire decade in the HBSs by Abadie (1997) and in my scaled-up data ${ }^{33}$.

My results can also be compared with studies on the evolution of inequality based on other kinds of data. Prados de la Escosura (2008) provided a long-run estimation based on a macroeconomic approach, calculating dispersion within and between the incomes of «workers» and "capitalists». His series show a rapid decrease in inequality in Spain between the mid-1950s and the mid 1960s, followed by a much slower diminishing trend since then and until the second half of the 1990s, when inequality would have started to go upwards again. The persistence I obtain is therefore quite consistent with Prados de la Escosura's calculations.

For the post-transition period it is also possible to use income tax data and assess the evolution of inequality in taxable income. By definition, however, the levels and trend do not need to coincide with those of disposable income: between both lie direct taxes, transfers and the impact of fraud. There are also other methodological differences, discussed in Ayala and Onrubia (2001): generally, tax-based studies use the taxpayer as the unit of analysis (as opposed to the household, and without applying equivalence scales) and have different universes (given by the effective income threshold to personal direct taxation). This category of taxpayers was also changing over the years: new taxpayers were coming in because the tax was being introduced, and also as an effect of fiscal drag. All of this explains why tax data generally show a higher level of inequality than survey data, and a worsening in (reported taxable) income distribution during the eighties (e.g. Lambert and Ramos 1997; Ayala and Onrubia 2001). The study closest to our

32 Oliver et al. (2001) do acknowledge the limitation of under-reporting in their source, around $30 \%$ of the National Accounts data for disposable income, although decreasing over time.

${ }^{33}$ I have calculated the indicator defined by Pijoan-Mas and Sánchez-Marcos (2010): head of household earnings (considering labour income and $2 / 3$ of self-employment income). The results show decreasing Gini indices: from 34 to 32 in market earnings, and from 32 to 29 considering also unemployment benefits. These numbers are quite compatible with those of the cited authors in trends, but at a slightly higher level. Since these results do not contrast with Abadie's (1997) with the original data (which, on the other hand, focus on individuals not suffering from unemployment), we can infer that differences in under-reporting do not affect the evolution of labour earnings inequality as much as it does for other incomes. 
discussion is that by Onrubia et al. (2007), which includes calculations for the "fiscal household» (thus homogenising the periods before and after the introduction of the separate filing option for married couples). The pre-tax income Gini index (taxable base with some adjustments) was found to increase continuously from 1982 to 1991 (31.68-42.00).

Alvaredo and Saez (2009) studied top income shares, obtaining the revenues from tax data and the population total (denominator) from National Accounts (therefore, their approach has the same comparability problems with my estimates, namely different income concept and no equivalisation). Their results show that the top $0.1 \%$ share was fairly constant over the 1960s and 1970s (around 1.87\%), with concentration starting to increase in the second half of the eighties $(2.14 \% \text { in } 1990)^{34}$. The same trend is shown in the share of the top 1\% (7.5-8.37\% in 1981 and 1990) and the top 10\% (32.61-35.35\% in the same years). It should come as no surprise that the figures are lower for disposable income: in my work, I obtain for the top $1 \%$ of households $6.47 \%$ in $1973,6.03 \%$ in 1980 and $7.15 \%$ in 1990 . Nevertheless, the increasing concentration in the last years is seen in both shources.

\section{REFERENCES}

Abadie, A. (1997): "Changes in Spanish Labor Income Structure During the 1980s: A Quantile Regression Approach». Investigaciones Económicas 21, pp. 253-272.

Alvaredo, F., and SAEZ, E. (2009): "Income and Wealth Concentration in Spain from a Historical and Fiscal Perspective». Journal of the European Economic Association 7 (5), pp. 1140-1167.

Ayala, L., and Onrubia, J. (2001): «La Distribución de la renta en España según Datos Fiscales». Papeles de Economía Española 88, pp. 89-112.

EUROSTAT (1999): «ECHP Data Quality». DOC.PAN 108/99, ECHP Working Group, European Comission, Luxemburg.

GoERLICH, F. J., and MAS, M. (2001): «Inequality in Spain 1973-91: Contribution to a Regional Database». Review of Income and Wealth 47 (3), pp. 361-378.

Instituto Nacional de Estadística (1983): Contabilidad Nacional de España. Base 1970. Años 1970-1980, 1981 Provisional y Avance de 1982. Madrid: INE.

Instituto Nacional De Estadística (2014): Contabilidad Nacional de España. Base 1986. Available at http://www.ine.es

LAmbert, P., and Ramos, X. (1997): «Horizontal Inequity and Vertical Redistribution». International Tax and Public Finance 4, pp. 25-37.

Oliver, J. (1997): «Ingreso, Consumo y Ahorro de las Familias: Propuesta de una Metodología Para la Explotación de la Encuesta de Presupuestos Familiares». Documentos de Trabajo FIES, 132.

Oliver, J.; Ramos, X., and Raymond-BarÀ, J. (2001): «Anatomía de la Distribución de la renta en España, 1985-1996: La Continuidad de la Mejora». Papeles de Economía Española 88, pp. 67-88.

34 Tables B2 and B3 in Alvaredo and Saez (2009). There are only three observations in the period 1961-1981, because of problems in the availability of the original data. 
Onrubia, J.; Rodado, M. C.; Díaz, S., and Pérez, C. (2007): «Progresividad y Redistribución a Través del IRPF Español: Un Análisis de Bienestar Social Para el Periodo 1982-1998». Hacienda Pública Española 183, pp. 81-124.

Pena Trapero, J. B. (dir.) (1996): Distribución Personal de la renta en España: Corrección y Modelización de la Información Básica: Desigualdad y Análisis. Madrid: Pirámide.

Pijoan-Mas, J., and Sánchez-Marcos, V. (2010): «Spain is Different: Falling Trends of Inequality». Review of Economic Dynamics 13, pp. 154-178.

Pou, L., and Alegre, J. (2002): «La Encuesta Continua de Presupuestos Familiares: Descripción, Representatividad y Propuestas de Metodología para la Explotación de la Información de los Ingresos y el Gasto», Documento de Trabajo 172/2002, Fundación de las Cajas de Ahorro Confederadas.

Prados De La Escosura, L. (2008): «Inequality, Poverty and the Kuznets Curve in Spain, 1850-2000». European Review of Economic History 12 (3), pp. 287-324.

SANZ, B. (1995): «La Articulación micro-macro en el Sector Hogares: de la Encuesta de Presupuestos Familiares a la Contabilidad Nacional», Papeles de trabajo, Instituto de Estudios Fiscales, 1995/27. 